\title{
Turning out to turn down the EU: The mobilisation of occasional voters and Brexit *
}

\author{
Lukas Rudolph ${ }^{\dagger}$
}

December 6, 2019

\section{Forthcoming in Journal of European Public Policy; author accepted manuscript}

\begin{abstract}
Large amounts of occasional voters participated in the Brexit referendum. How did this increase in turnout affect the outcome of the referendum? To thoroughly explore this question we exploit exogenous variation in voting costs on the local level. Large amounts of rainfall on election day made voting slightly more inconvenient in some areas of the UK. Using this rainfall in an instrumental variable approach, we can assess the voting behaviour of citizens whose benefits of voting just surpass costs under normal circumstances. We show that these voters predominantly supported Leave. Hence, the increase in turnout led to higher Leave support. Subsequently, we explore the likely reason for this observation with survey data. We find evidence that occasional voters were not more likely to support Leave in general, but that the mobilisation of Leaveleaning vs. Remain-leaning occasional voters was lopsided: Leave-leaning occasional voters were more likely to turn out. In a broader picture, our research highlights that the issue-specific mobilisation of low-propensity voters is important for explaining electoral outcomes. This is particularly so in referendums with weak partisan preferences, and where singular issues dominate voter decision making.
\end{abstract}

Keywords: Brexit; United Kingdom European Union membership referendum; turnout; electoral participation; electoral outcomes; voting behaviour; voting costs; rainfall; instrumental variable approach

*I thank John Aldrich, Liam Beiser-McGrath, Matthias Fatke, Sona Golder, Arndt Leininger, Ingrid Mauerer, Steffen Murau, Oliver Pamp, Christopher Prosser, Franziska Quoss, Paul Thurner, seminar audiences at LMU Munich and ETH Zurich as well as participants at the 2016 EITM summer institute, and the 2017 MPSA conference for helpful comments and suggestions. UK rainfall data provided by the UK Met Office is kindly acknowledged. I acknowledge financial support by a dissertation research grant of the German National Academic Foundation.

${ }^{\dagger}$ LMU Munich and ETH Zurich; Email: lukas.rudolph@gess.ethz.ch 


\section{Introduction}

Low turnout likely leads to both representation being skewed and policy being shifted towards the interests of voters as opposed to the eligible population (Lijphart, 1997). Against this backdrop, decreasing rates of electoral participation in the last decades in many established democracies are worrying. But who participates if turnout increases from such low baselines? We investigate this question for a particularly relevant case: the United Kingdom European Union membership ('Brexit') referendum on June 23rd, 2016, where turnout reached $72 \%$ - the last UK general election that saw turnout above $70 \%$ was in 1997, and turnout for European Parliament elections never reached $40 \%$ in the UK. Pollsters and forecasters had both seen a vote for Remain as likely outcome of the election, the Leave share of $51.9 \%$ came as a surprise for many, and the role of turnout has been publicly debated in the aftermath. We ask whether this high level of turnout had an effect on the outcome of the referendum.

A recent literature draws on quasi-experimental variation in participation costs due to institutional design and suggests that turnout matters. Particularly, left-of-center parties and positions profit in many contexts (Fowler, 2013, 2015; Bechtel et al, 2016; Potrafke and Roesel, 2018), although in particular settings it is right-of-center positions (Cepaluni and Hidalgo, 2016: Berinsky, 2005), both the left and right (Finseraas and Vernby, 2014) or the political center (Ferwerda, 2014) that see increases in electoral support.

This picture is reinforced by another set of studies using changes in weather conditions as instrumental variable (IV) for turnout: E.g., Hansford and Gomez (2010) report substantial partisan effects of voter turnout in the US, benefiting the Democrats. Partisan effects are noted for rainfall in other elections as well (see Arnold and Freier, 2016, for an overview).

The above mentioned research largely studies presidential, legislative or local elections. However, with referendums the incentives for particpation follow a different calculus. Voters are asked to vote for a single referendum question that may or may not be salient for them. This makes it even more important to study the role of who participates in referendums to voice their opinion.

Best studied is the Swiss case. Survey evidence indicates that outcomes of Swiss referendums are by and large representative (e.g., Leininger and Heyne (2017)). However, exogenous increases in turnout (due to compulsory voting) led to increased support for leftists policy Bechtel et al, 2016) and less educated voters were most sensitive to variations in voting costs (due to postal voting) (Hodler et al, 2015). For EU referendums, Qvortrup (2016) reports a strong cross-country correlation between turnout levels and EU/EEC approval rates for all EU/EEC referendums between 1972 and 2015. The present study picks up this question with a causal identification strategy for the Brexit case. This fills an important gap, as most 
EU-related research on voting behavior focuses on factors that influence vote choice, not participation (see for an extensive treatment Hobolt and Tilley, 2014).

Given the likely endogenous relationship between turnout and electoral outcomes, we follow an established literature that uses rainfall as exogenous instrument for participation (Arnold and Freier, 2016). This is feasible, as exceptionally strong rainfall on election day affected parts of the country. An additional first differences design warrants against geographic confounders, focusing on the differential increase in turnout from the 2014 European Parliament election. In line with earlier research we find that rainfall depressed turnout, i.e. with good weather we observe a larger increase in turnout. We then use this weatherinduced variation in an IV set-up to assess the electoral effects of turnout. Our estimates imply that an increase in turnout of one percentage point led to an increase in the Leave share of around 0.75 percentage points. Placebo tests on unaffected outcomes (Brexit postal voting) lend support to the identification strategy. The implications of these findings differ depending on two potential preference structures of all low-propensity voters in the UK. Is it more likely that all occasional voters were leaning towards Leave, or was it rather the case that among all occasional voters those leaning towards Leave were mobilised to a particular extent? Evidence from pre-referendum survey data (British Election Study) indicates that Leave/Remain support was likely similar between occasional and regular voters in principle. But among occasional voters, Leave-leaning respondents report a higher turnout intention.

Our reserach contributes to three broader questions. First, our findings link to the observation that low propensity voters have heterogeneous preferences (Finseraas and Vernby, 2014). The results indicate that the mobilisation potential of occasional voters matters even if overall turnout levels are, as in the case at hand, relatively high already. Hence, whenever issue salience, campaigning or other external factors succeed in mobilising some occasional voters over others, this should be consequential for electoral results.

Second, our research contributes to a small literature that assesses the particular role of turnout in referendums and ballot initiatives. It has e.g. been shown for ballot initiatives in the US that the saliency of issues influences turnout (Biggers, 2011; Smith, 2001), but likely mobilises specific segments of the population over others (Campbell and Monson, 2008). We add an important case in which mobilisation was lop-sided despite a national-level relevance of the referendum question.

Third, our results contribute to understanding 'Brexit': The present analysis is among the first to use a causal identification strategy to investigate the role of turnout, focusing particularly on the role of the increase in turnout. Various observers see differential mobilisation as important for explaining Brexit (Clarke et al, 2017). The larger part of the literature reports associations of high turnout with Leave (Zhang, 2018; Goodwin and Heath, 2016, 
Becker et al, 2017), emphasizing that "Leavers were more motivated to vote than Remainers [as] plausible idea" (Clarke et al (2017), 209). But this finding is not unequivocal, e.g. Manley et al (2017) report that higher turnout was associated with Remain. A related argument focuses on the role of changes in turnout. These studies highlight the participation gap between different socio-economic strata. As a closing of the participation gap would partly favour Remain (e.g. the old/young divide, see Birch (2016)) but partly also Leave (e.g. the high/low education divide, see (Evans and Menon, 2017)) these researchers come to differing conclusions. Note that independent of us and drawing on the same case with a different identification strategy, Leslie and Arl (2018) show that rainfall was negatively related to turnout levels and predominantly induced Leave voters to stay home. Hence, they show as well that the rainfall-induced turnout decline was inconsequential for the overall Leave decision.

Finally, the paper adds to a recent, growing literature Arnold and Freier, 2016 that links weather conditions to electoral participation in many settings. We show that this likely holds as well for referendums.

\section{The Brexit case}

Following longstanding internal challenges of EU membership both in the broader public and the Conservative Party, then Prime Minister David Cameron promised in 2013 a referendum if he won the next general election. This was held on June 23rd, 2016, on the question "Should the United Kingdom remain a member of the European Union or leave the European Union?". Against expectations of both pollsters ${ }^{1}$ and betting market: ${ }^{2} 51.89 \%$ of voters opted for 'Leave the EU'. High turnout accompanied the referendum: $72.21 \%$ of registered voters turned out.

Various explanations for the referendum outcome have been proposed: E.g, on the aggregate level, correlations between higher Leave share, lower average education, income and age (Arnorsson and Zoega, 2018) as well as unemployment (Zhang, 2018) have been noted. Geography has been found to matter less, once socio-demographic factors are taken into account (Manley et al, 2017). Additionally, the immigration issue (Goodwin and Milazzo, 2017), national attachment (Clarke et al, 2017), as well as economic factors (manufacturing, inequality) (Becker et al, 2017) have been highlighted. As briefly summarized in the introduction, turnout levels and differential increase in turnout have been prominently dis-

\footnotetext{
${ }^{1}$ According to The Huffington Post, Remain was leading in $73 \%$ of its simulations (see http://elections. huffingtonpost.com/pollster/uk-european-union-referendum).

${ }^{2}$ They saw an $85 \%$ likelihood for Remain just before election day (data compiled by PredictWise, see http://predictwise.com/politics/uk-politics).
} 
cussed as well, both as independent and mediating factor for the Brexit vote (see Appendix Section A.1 for a detailed summary).

\section{Data}

We draw on 2016 Brexit referendum and 2014 European Parliament election (EE) results in the UK, obtained from the Electoral Commission for 381 units. $3^{3}$.

Data on rainfall on election day is obtained from the UK Met Office ${ }^{4}$ and reflects daytime rainfall (0900 - 2100 hours) in millimetres $(\mathrm{mm})$ for 248 weather stations across the UK on June 23rd, 2016. Election day rainfall was especially severe in the south and east of the country, where even some polling stations had to be closed $!^{5}$ Rainfall mostly affected regions of the country with an average annual rainfall below the country average $5^{6}$ Drawing on shapefiles obtained from the UK Data Service. $7^{7}$ we calculated rainfall per local authority. For this, we averaged the rainfall of weather stations located within a local authority or, if an administration had no weather station located in it, within a $20 \mathrm{~km}$ radius of its centroid (see Figure 1).

We additionally gathered economic and socio-demographic information on local administration level from the UK Office of National Statistics: This is data on ethnic composition and migration rates ${ }^{8}$ as well as population size, density, age structure, local economy ${ }^{9}$ (all for 2011) and labour market (for 2016)

Summary statistics are displayed in Appendix Table A.1.

\footnotetext{
${ }^{3}$ Available at http://www.electoralcommission.org.uk/ for unitary authorities (England, Scotland and Wales), non-metropolitan districts and metropolitan boroughs (England), and Northern Ireland. All of these are termed "local authority" in the following. Note that we draw on Northern Ireland as a single observation: It is considered by the UK Electoral Commission as singular counting unit and referendum outcomes are not available on local goverment level. While data on parliamentary constituency level exists, European Parliament election results, which are crucial as a baseline estimate of Ukip-support (see section 4), are not available on this level from neither The Electoral Office of Northern Ireland (EONI) nor other sources the EONI would be aware of (personal communication with EONI, December 3rd, 2019)

${ }^{4}$ Through personal communication with the Weather Desk Team of the Met Office, July 6 th, 2016.

${ }^{5}$ See http://www.metoffice.gov.uk/climate/uk/summaries/2016/june.

${ }^{6}$ Comp. the spatial distribution of annual UK rainfall in the last decade and June 2016 anomaly rainfall at http://www.metoffice.gov.uk/climate/uk/summaries/anomacts.

${ }^{7}$ See https://census.edina.ac.uk/bds.html

${ }^{8}$ Available from http://www.nomisweb.co.uk/census/2011/.

${ }^{9}$ I.e. share of employed in high, and respectively low skilled labor.

${ }^{10}$ Available from http: //www . ons .gov .uk/
} 
Figure 1: Rainfall in the United Kingdom on election day

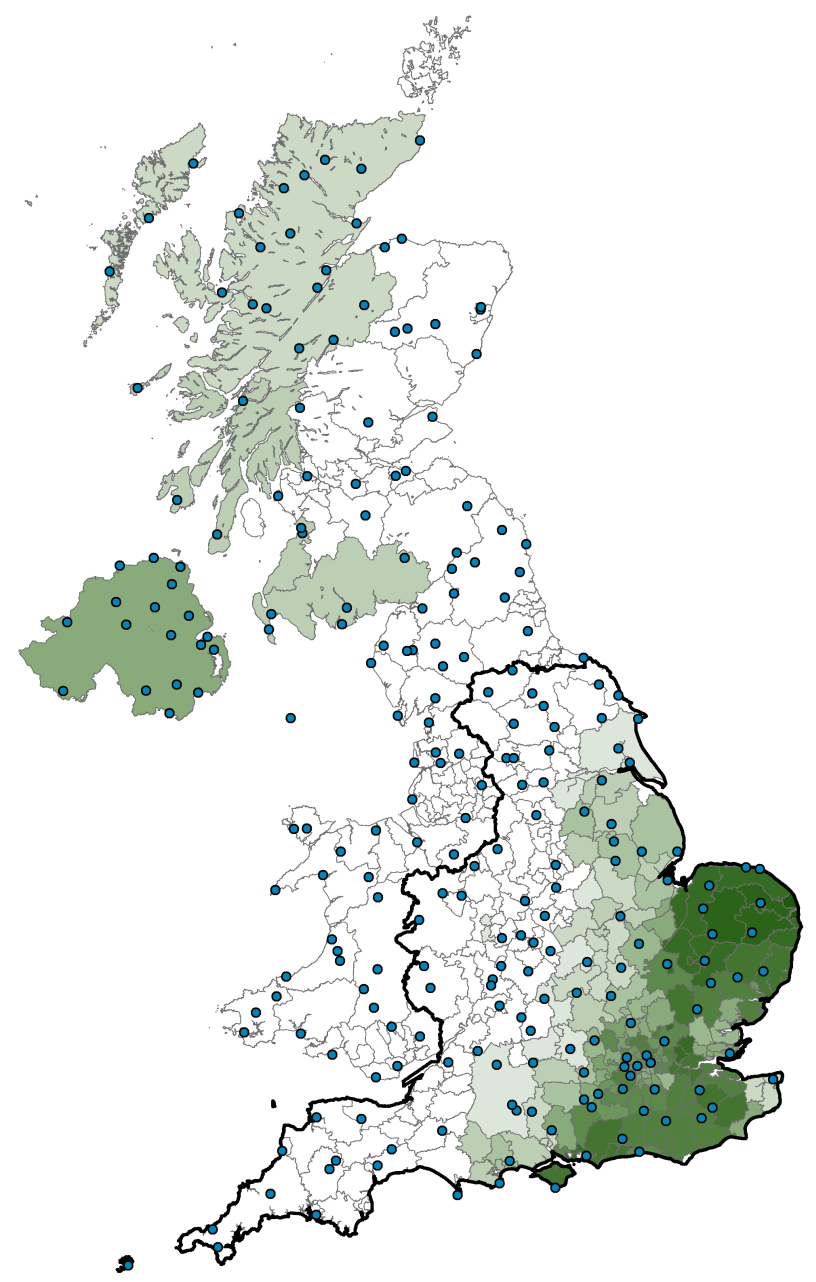

Figure depicts the 248 weather stations in the UK (dots) and day-time rainfall (0900-2100h) on June 23rd, 2016 (referendum day). Rainfall in local authorities varies from no rain (white) to slight rain (light green $(0.2 \mathrm{~mm})$ ) and heavy rain (dark green $(42.2 \mathrm{~mm})$ ). Black outline denotes the 'adjacent sample' (English regions with at least one unit experiencing rainfall).

\section{Research design}

Levels of electoral participation and aggregate vote choice are likely correlated (Hansford and Gomez, 2010), hence endogeneity has to be addressed. In line with earlier research (see Arnold and Freier, 2016) we propose to use rainfall as an instrumental variable (IV), affecting the turnout decision (first stage) but not vote choice. We use this variation to assess the effect of participation on referendum outcomes (second stage).

Most prior studies using rainfall as IV draw on many election-years over time. Then, rainfall is arguably as-if-randomly distributed over space (but see for a recent note of caution Cooperman (2017)). We, however, exploit an extreme rainfall event that is geographically 
concentrated in specific areas ${ }^{11}$ We hence have to preclude that the instrument picks up spatial confounders related to turnout and Brexit preferences. We adopt three complementary strategies in this regard:

First, we explicitly take geography into account. On the one hand, we include indicator variables for the four countries of the UK as well as London. On the other hand, for our preferred estimation models, we restrict the sample to 'rainy' regions in England (termed 'adjacent sample' in the following) $!^{12}$ As unobserved confounders are geographically clustered (Johnston and Pattie (2006), Chap. 7; Johnston et al (2017); Rodden (2010)), the potential for biased estimates is lowered with this strategy (Tobler, 1970). In a nutshell, we restrict the control group for the rainfall treatment to observations in east and south England that stem from an area with similar political discourse and similar political structure (e.g. concerning political representation and Brexit debate ${ }^{13}$. With Appendix Table A.2 and Appendix Figure A.1 we show that this improves balance in observables, making it likely that balance in unobservables improves as well (see Appendix Section A.2 for details). We can see from Appendix Table A.2 that local authorities with rainfall differ on average from local authorities without rainfall in several respects (share of population over 60, unemployment share and trend, population density, labor market structure, migrant and ethnic white share). This was to be expected as the rainfall event predominantly hit the south and east of England as well as some areas of Scotland and Northern Ireland and it is plausible that these specific areas are not directly comparable to an average local authority from the rest of the UK. More importantly for our research design, then, Appendix Table A.2 shows that differences-in-means between treated and control group in the full sample reduce for many important covariates (for share of unemployed, trend in unemployment, difference in high skilled labour, difference in 2014 European Election Ukip share) if we restrict the comparison to the adjacent sample. These changes support the argument that with the adjacent sample we are increasing the ex-ante comparability of the treated and control group. Note, however, that some covariate-differences barely change (population density, share in lowskilled labour, share of migrants, share of ethnic white population) and for one covariate the difference increases (share of population over 60). To get a better picture of the overall changes in associations we therefore as well assess how the strength of correlations between

\footnotetext{
${ }^{11}$ We observe no rainfall variation in Wales, North East/West England and barely variation in Scotland (only three of 32 units experience rainfall $>1 \mathrm{~mm}$, none $>2.5 \mathrm{~mm}$ ).

${ }^{12}$ Region is the highest tier of administrative subdivision. The approach excludes observations in North East England, North West England, Scotland, Wales and Northern Ireland.

${ }^{13}$ The discourse was much different in the countries of the UK. E.g. Arnorsson and Zoega (2018) report that predictors of the Brexit vote differ between England/Wales and Scotland/Northern Ireland. They propose that decision making in the latter two countries follows a different rational as voters factor in concerns for the 1998 peace accord (NI) and independence (Scotland).
} 
our metric rainfall measure and the covariates changes when restricting the sample. As reported in Appendix Figure A.1 we can again draw two main conclusions: On the one hand, there are substantial correlations between observable characteristics of local authorities and rainfall. This suggests an empirical strategy where we control for the said variables. On the other hand, the statistical strength of these associations shrinks substantially with the adjacent sample: Then, only two out of twelve variables are significantly correlated with rainfall, compared to five for the full sample. As well, in a Q-Q plot of empirically observed p-values against a theoretically ideal uniform distribution the maximum distance to the uniform distribution decreases by $27 \%$ for the adjacent sample.

Second, we use a first difference design, invoking only the assumption of unconfounded counterfactual trends (Lechner, 2011). This assumes that the dependent variable (Ukip/Leave support) would on average have been on a similar trend between the units of the control (no rain) and the treatment (rain) group, had the treatment not occurred. We thus assume that rainfall did not by chance affect regions on different Leave-support trends. While we cannot test this directly, Appendix Figure A.2 shows that Ukip support changed in parallel between the 2009 and 2014 European Parliament elections in regions with no, low, medium or large amounts of rainfall for both the full and the adjacent sample. The strategy implicitely controls for time-constant confounders, i.e unit characteristics that affect voting behavior similarly in 2014 and 2016. It hence sets weaker assumptions compared to level regressions that assume as-if-random distribution of rainfall with respect to counterfactual Leave support. For the differencing we use 2014 European Parliament election turnout and Ukip vote as baseline. The European elections are particularly suitable for three reasons: They were concerned with EU membership as central issue (Treib, 2014); they follow a PR electoral system, giving no incentives for strategic voting on constituency level (Cox, 1997); reporting of European election results matches referendum counting areas.

This then leads to the following estimation strategy for observations $i$ Angrist and Pischke, 2009): Main dependent variable is the first difference in the 2016 Leave share and the 2014 Ukip share $(\Delta Y)$. Main independent variable is the first difference in 2016 and 2014 turnout $(\Delta T)$. Substantively, this puts the focus on the research question what the impact of the differential increase in turnout implies for Leave support. As $\Delta T$ is endogenous, we have to proceed in two steps. First, we instrument $\Delta T$ with rainfall on election day in mm, denoted as $R$. Hence the first stage of the IV set-up is given by

$$
\Delta T_{i}=\alpha_{1 i}+\beta_{1} R_{i}+\mathbf{X} \gamma_{1}+\epsilon_{i}
$$

This allows us to assess the effect of rainfall on turnout (coefficient $\beta_{1}$ ) and to calculate predicted values of the turnout increase that stem from exogenous variation in rainfall $\left(\Delta T_{i}\right)$. 
These predictions are then plugged into the second stage of the IV regression:

$$
\Delta Y_{i}=\alpha_{2 i}+\beta_{2} \Delta T_{i}+\mathbf{X}_{i} \gamma_{2}+\epsilon_{i}
$$

Eq. (2) allows us to estimate the effect of the turnout increase on the increase in Leave support (coefficient $\beta_{2}$ ). Depending on specification, we include a vector $\mathbf{X}$ of socio-economic and political controls to increase the precision of estimates and control for potential confounders ${ }^{14}$ The control variable vector has to be used similarly for the first stage and is therefore included in eq. (1). In the results section, we provide estimations for the full sample (all local authorities from the UK) and the results for the adjacent sample side by side. While the former allow a broader claim on the relationship between the changes in turnout and Leave support, the latter are our preferred specification, as assumptions necessary for causal identification are more likely to hold. As well, we provide additional tests with Leave share as dependent variable (controlling for the lagged outcome), to guard against potential model misspecifications.

Table 1 shows first stage results. As expected, we find a negative relation between rainfall and the first difference in turnout: One millimetre of rainfall is related to a turnout decrease of around 0.1 percentage points (model 4, adjacent sample, with controls). This implies, given average election day rainfall of $5.99 \mathrm{~mm}$, an average effect of -0.59 percentage points (model 4). This is similar in size to what the literature finds (Arnold and Freier, 2016). Instrument relevance is supported by F-statistics well above 10 (recommended as rule of thumb (Angrist and Pischke, 2009)).

Finally, Appendix Section A.2 discusses placebo tests that lend credibility to the identification strategy. Note that it is in principle not testable whether we would really have observed parallel trends, had there been no rainfall. But, as suggested by Angrist and Pischke (2009), we assess whether referendum day rainfall is related to unaffected outcomes that are determined by the same structural factors. We report results for changes in pretreatment postal voting applications and pre-treatment postal ballot turnout. Regressions follow the set-up of Table 1. We argue that structural shifts in participation patterns should extend to postal voters as well, while rainfall could not affect the decision for a postal vote. Consequently, we find substantially small and insignificant associations to rainfall on election day for both variables and in both the full and adjacent sample (Appendix Table A.3).

\footnotetext{
${ }^{14}$ These are: share of population being ethnic white; migrated from outside the UK; aged 20-30; aged 60+; unemployed; employed in high skilled labour; in low skilled labour; the change in 2015-2016 unemployment; population density; population size (logged); share of Ukip support in last European Parliament election (for non-delta specification of explanatory variable only); regional indicators for Scotland, Wales, Northern Ireland, England without London (reference category), London.
} 
Table 1: Effect of election day rainfall (in $\mathrm{mm}$ ) on turnout

\begin{tabular}{lcc|cc}
\hline \hline & \multicolumn{3}{c}{ Dep. var.: 2016 referendum - 2014 EE TO } \\
& \multicolumn{2}{c}{ Full sample } & \multicolumn{2}{c}{ Adjacent sample } \\
& $(1)$ & $(2)$ & $(3)$ & $(4)$ \\
\hline Average election day rainfall $(\mathrm{mm})$ & $-0.11^{* *}$ & $-0.071^{* *}$ & $-0.21^{* * *}$ & $-0.098^{* * *}$ \\
& $(0.047)$ & $(0.028)$ & $(0.048)$ & $(0.026)$ \\
& & & & \\
Constant & $38.2^{* * *}$ & $24.0^{* * *}$ & $39.4^{* * *}$ & $33.2^{* * *}$ \\
& $(0.30)$ & $(7.36)$ & $(0.33)$ & $(6.53)$ \\
Region and socio-economic controls & No & Yes & No & Yes \\
\hline N & 381 & 381 & 275 & 275 \\
Adj. R2 & 0.0079 & 0.69 & 0.042 & 0.77 \\
F & 5.84 & 46.7 & 19.2 & 53.4 \\
\hline \hline
\end{tabular}

Regression of election day rainfall in mm on difference in 2016 referendum and 2014 European Election (EE) turnout (TO). Robust standard errors in parentheses. Control variables included (as indicated): share of population being: ethnic whites; immigrants (from outside UK); aged 20-30; aged 60+; unemployed; employed in high skilled labour; employed in low skilled labour; change in 2015-2016 unemployment; population density; population size (logged); indicators for London, Wales, Scotland, Northern Ireland. Full sample: all observations from the UK; adjacent sample: English regions with at least one local authority experiencing rainfall. F-statistic in model 2 from parameter test excluding Northern Ireland indicator. Full models in Appendix Table A.4. ** $(*, * * *)$ indicates $\mathrm{p}<0.05(0.1,0.01)$

\section{The role of participation for the referendum outcome}

Table 2 reports the IV regression for the full (models 1-3) and the adjacent sample (models 4-6), with the share of Leave (models 2, 4) and the difference in Leave share and 2014 European Election Ukip share (models 1, 3, 4, 6) as dependent variable. As can be seen, estimated effects are larger in the full sample but also estimated with less precision - they are however throughout clearly positive and statistically significant at least at the $10 \%$-level, implying a positive effect of the weather-induced turnout increase on the Leave vote. Turning to the adjacent sample in models 4 to 6 , effects are more precisely estimated. They range from 0.74 to 0.88 between the models, i.e. with a one percentage point larger turnout increase, the (change) in Leave support increases by around 0.8 percentage points. Coefficient estimates are similar in size irrespective of including socio-demographic and geographic controls (models 2 and 3) or of using a first difference design (models 4 and 6) compared to a lagged dependent variable set-up (model 5 ). The effect is estimated with sufficient precision (significant at least on the 5\%-level) in most models. As well, it is comforting that throughout all models the estimated coefficients are substantively similar and statistically 
Table 2: Instrumental variable regression: Effect of turnout change on Leave vote/change

\begin{tabular}{|c|c|c|c|c|c|c|}
\hline & \multicolumn{3}{|c|}{ Full sample } & \multicolumn{3}{|c|}{ Adjacent sample } \\
\hline & $(1)$ & $(2)$ & $(3)$ & $(4)$ & $(5)$ & $(6)$ \\
\hline & $\begin{array}{l}\text { Diff. Leave - } \\
\text { Ukip share }\end{array}$ & $\begin{array}{c}\text { Leave in } \\
\%\end{array}$ & $\begin{array}{c}\text { Diff. Leave - } \\
\text { Ukip share }\end{array}$ & $\begin{array}{l}\text { Diff. Leave - } \\
\text { Ukip share }\end{array}$ & $\begin{array}{c}\text { Leave in } \\
\%\end{array}$ & $\begin{array}{c}\text { Diff. Leave - } \\
\text { Ukip share }\end{array}$ \\
\hline 2016 referendum - & $2.60^{*}$ & $0.66^{* *}$ & $1.63^{*}$ & $0.78^{* *}$ & $0.74^{* * *}$ & $0.88^{* *}$ \\
\hline 2014 EE TO & $(1.34)$ & $(0.29)$ & $(0.85)$ & $(0.34)$ & $(0.28)$ & $(0.39)$ \\
\hline Constant & -74.4 & $34.4^{* * *}$ & 8.08 & -7.56 & 18.2 & 12.1 \\
\hline & $(50.9)$ & $(10.4)$ & $(22.7)$ & $(13.0)$ & $(12.7)$ & $(15.3)$ \\
\hline $\begin{array}{l}\text { Region and socio- } \\
\text { economic controls }\end{array}$ & No & Yes & Yes & No & Yes & Yes \\
\hline $\mathrm{N}$ & 381 & 381 & 381 & 275 & 275 & 275 \\
\hline
\end{tabular}

Instrumental variable regression (two-stage least squares) with rainfall (in $\mathrm{mm}$ ) as instrument for turnout increase on Leave support (models 2 and 5)/difference in 2016 Leave over 2014 European Election (EE) Ukip support (models 1, 3, 4, 6). Robust standard errors in parentheses. Control variables included (as indicated): share of population being: ethnic whites; immigrants (from outside UK); aged 20-30; aged 60+; unemployed; employed in high skilled labour; employed in low skilled labour; change in 2015-2016 unemployment; population density; population size (logged); indicators for London, Wales, Scotland, Northern Ireland. Full sample: all observations from the UK; adjacent sample: English regions with at least one local authority experiencing rainfall. F-statistic in model 2 from parameter test excluding Northern Ireland indicator. Full models in Appendix Table A.5. ** $(*, * *)$ indicates $\mathrm{p}<0.05(0.1,0.01)$

significant. Overall, Table 2 provides a clear picture: The strong turnout increase observed with the Brexit referendum was related to a strong increase in Leave support.

We now discuss how these results compare to a simple OLS approach ignoring endogeneity. Results are presented in Appendix Table A.6. We mirror the model set-up of Table 2 . i.e. we focus on the association between turnout increase and increase in Leave support. This association is strongly negative in a mere correlation of the two variables. Once control variables are introduced, it shrinks in size for the full sample and is reduced to zero for the adjacent sample. This underscores the importance of our approach, taking the endogeneity between the turnout decision and electoral choice into account. Only then are we able to ascertain that the turnout increase is indeed positively related to Leave support as reported by other researchers (see e.g. Zhang (2018)). Note that correlations between turnout levels and Leave support levels are positive (correlation coefficient of 0.11 for the full, and 0.05 for the adjacent sample), but this positive association already flips signs when including 2014 Ukip support, i.e. a lagged dependent variable, to the regression.

The substantive relevance of the IV estimates presented in Table 2 can be assessed using the framework of Fowler (2015) (details in Appendix Section A.4). Based on the turnout 
increase and the increase in Leave support, we can disentangle the preferences of occasional voters (voting only in good weather) and regular voters (voting also in rain). Importantly, this only allows us to assess the preferences of occasional voters that actually participated. The Fowler-approach implies a Leave share of $109.5 \%$ [78.2, 188.4] among this occasional voter population and a preference gap of 56.2 [24.7, 135.2] percentage points between regular and occasional voters. The point estimate for the share of Leave support in the occasional voter population exceeds $100 \%$. This hints to the possibility of spill-over effects and/or direct effects of rainfall on Leave support (comp. Leslie and Arl (2018), who find evidence for such direct effects). Note that the size of the point estimates has to be interpreted cautiously, though, due to the wide confidence interval and strong assumptions; nonetheless, results give numeric support that preferences on EU membership differed strongly between occasional voters that participated in the referendum and regular voters.

To summarize, the IV estimates consistently indicate that increases in turnout due to weather conditions are strongly related to increases in Leave support. Results imply that voters whose participation decision was influenced by rainfall (and which therefore abstained) were especially likely to support Leave. As it was on average Leave supporters that were deterred from voting due to bad weather, rainfall played no role for the outcome of the referendum. However, as those voters that were marginal to slight increases in voting costs seemed to be strongly leaning towards Leave, this indicates that the strong overall increase in turnout likely played a decisive role for the success of the Leave campaign.

\section{Robustness tests}

For completeness, reduced form results are presented in Appendix Table A.7 and show a consistently negative effect of rainfall on Leave support - as argued above, this is due to the rainfall-induced decrease in turnout. We conduct several robustness test to further assess the validity of the IV estimates. Already included in the regressions presented above is the consistency of findings for the broader sample of the full UK compared to the adjacent sam-

ple with higher internal validity (comp. models 1-3 to 4-6 of Table 2). As well, modeling choices, in particular the specification of the model with a lagged dependent variable compared to a first differences design does not affect our interpretation (comp. models 5 and 6 of Table 2). Additional robustness tests are presented in Appendix Section A.5. First of all, for comparison, we as well provide results instrumenting turnout levels. These are reported in Appendix Table A.8. For instrument relevance coefficients are slightly smaller but otherwise comparable. The IV regressions confirm the positive relationsship between turnout and Leave support, but the relationship is estimated with adequate precision only in the 
adjacent sample. Second, to probe against functional form misspecifications we calculated effects with a binary instrument. The binary instrument is operationalized as local authorities experiencing above median rainfall. The instrument is relevant and reduces turnout in all specifications (comp. Appendix Table A.9). IV estimates show a positive, significant relationsship to Leave support, comparable in size to Table 2 (see Appendix Table A.10). Finally, expanding the 'adjacent sample' to include Northern Ireland and Scotland (where small amounts of rainfall were observed) allows us to keep more observations. This approach leads to very similar estimates (see Appendix Table A.11). These specifications are theoretically less preferred, though, given the differing Brexit discourse in these parts of the UK (Arnorsson and Zoega, 2018).

\section{$7 \quad$ Survey evidence on Brexit preferences in the broader occasional voter population}

Large amounts of occasional voters turned out for the Brexit referendum. As presented above, we can identify the preferences of those occasional voters that were marginal to rainfall with the IV estimation. Overall, our results imply that Leave-support was much stronger in the occasional voter population that participated only in good weather compared to the regular voting population. However, the broader implications of our finding depend on the preferences of occasional voters that would not participate even with good weather in this referendum. The IV results do not allow us to infer something on this population. We hence turn to survey data to put our results into perspective, and to learn on the likely structure of Brexit preferences in the overall population of occasional voters.

Two potential structures of participation and preferences are consistent with the IV results. The first potential structure (denoted as S1) would imply that all occasional voters are generally leaning towards Leave. Any turnout increase then leads to a closer approximation of the true preferences of all regular and occasional voters in the UK and is, in the terms of Lijphart (1997), equality enhancing per se. An alternative potential structure (denoted as S2) would be that Leave-leaning occasional voters were overproportionally drawn to the polls relative to Remain-leaning occasional voters. The referendum outcome is then a function of mobilization and in the terms of Hansford and Gomez (2010) increases in turnout are related to increases in electoral volatility. This is, because occasional voters hold weak partisan attachements (Hansford and Gomez, 2010) and/or because the election-specific mobilization potential of certain segments of voters is higher (Biggers, 2011; Campbell and Monson, 2008). Importantly, the implications of these two potential structures differ - with S1 high turnout 
brings about a closer approximation of referendum outcomes to true preferences, with S2 the true preference distribution is unknown and the electoral outcome depends on the relative degree of mobilization of latent Leave vs. Remain supporters.

A theoretical model of voter turnout is helpful to get to an answer on this question. We draw on the canonical framework of Riker and Ordeshook (1968). The participation decision of a voter depends on her rewards from voting, $R$, her benefit from the favoured electoral outcome $(B)$ weighted with the subjective probability of casting a decisive vote $(P)$, her (expressive) utility derived from the act of voting $(D)$ and her voting costs $(C)$. A voter participates in an election if her reward from voting is positive,

$$
R=P B+D-C>0
$$

Rainfall $(r)$ is affecting the voting cost function $C_{i}(r)$ of voters, where we can expect $\partial C_{i}(r) / \partial r>0$ (voting costs increase with rain). We can expect voter $i$ to abstain when the (expected) utility of voting without rain is smaller than the increase in voting costs due to rain, thus if

$$
R_{i}(r=0)<\partial C_{i}(r) / \partial r
$$

With survey data, we want to find indications whether all occasional voters are generally leaning towards Leave (S1) or whether participation intention among occasional voters was correlated with Leave/Remain preference (S2).

We draw on a rolling cross-sectional survey in the pre-referendum weeks, the British Election Study ${ }^{15}$ We define occasional voters as those respondents who report abstention in the 2005, 2010 and/or 2015 general election. ${ }^{16}$

With S1, the IV effects are only consistent with a population of occasional voters that leans towards Leave on average. We test this potential explanation by comparing the selfstated Leave support among all occasional voters (irrespective of whether they actually voted or not) and all regular voters. Based on a Wald test, we find no significant difference between these populations (see Table 3, column 1). The occasional-voter population even seems to be leaning slightly towards Remain.

An alternative explanation is provided by S2, which implies that the mobilization of Leave leaning voters was relatively stronger. The temporal structure of the survey data

\footnotetext{
${ }^{15}$ We used the EU Referendum Daily Campaign Data from the British Election Study Internet Panel, which is an online sample of YouGov panel members. The BES surveyed each day 500-770 respondents from Great Britain beginning 48 days to one day before the referendum. Data is available online at http://www.britishelectionstudy.com/data-object/ wave-8-of-the-2014-2017-british-election-study-internet-panel-daily-file/.

${ }^{16}$ The abstention variable is recalled. We assume that recall bias is affecting Leave- and Remain-leaning respondents similarly.
} 
Table 3: Survey evidence

\begin{tabular}{|c|c|c|c|c|c|}
\hline & \multirow{2}{*}{$\begin{array}{c}\text { Full sample } \\
(1) \\
\text { Share of } \\
\text { Leave support }\end{array}$} & \multicolumn{4}{|c|}{ Sample of occasional voters } \\
\hline & & $\begin{array}{l}\quad(2) \\
\text { Very high interest } \\
\text { in Referendum }\end{array}$ & $\begin{array}{c}(3) \\
\text { Very high } \\
\text { turnout intention }\end{array}$ & $\begin{array}{c}(4) \\
\text { Very high } \\
\text { turnout intention }\end{array}$ & $\begin{array}{c}(5) \\
\text { Very high } \\
\text { turnout intention }\end{array}$ \\
\hline $\begin{array}{l}\text { Subgroup } 1 \\
\text { mean }\end{array}$ & $\begin{array}{c}\text { Regular } \\
\text { voters } \\
0.507 \\
(0.00470)\end{array}$ & $\begin{array}{c}\text { Remain } \\
\text { supporters } \\
0.505 \\
(0.0132)\end{array}$ & $\begin{array}{c}\text { Remain } \\
\text { supporters } \\
0.666 \\
(0.0134)\end{array}$ & $\begin{array}{c}\text { Other issue most } \\
\text { imp. for resp. } \\
0.688 \\
(0.0187)\end{array}$ & $\begin{array}{c}\text { Other issue most } \\
\text { imp. for resp. } \\
0.759 \\
(0.0150)\end{array}$ \\
\hline $\begin{array}{c}\text { Subgroup } 2 \\
\text { mean }\end{array}$ & $\begin{array}{l}\text { Occasional } \\
\text { voters } \\
0.493 \\
(0.00918)\end{array}$ & $\begin{array}{c}\text { Leave } \\
\text { supporters } \\
0.541 \\
(0.0129)\end{array}$ & $\begin{array}{c}\text { Leave } \\
\text { supporters } \\
0.719 \\
(0.0126)\end{array}$ & $\begin{array}{c}\text { Sov./Imm. most } \\
\text { imp. for resp. } \\
0.807 \\
(0.0190)\end{array}$ & $\begin{array}{c}\text { Econ. most } \\
\text { imp. for resp. } \\
0.652 \\
(0.0320)\end{array}$ \\
\hline $\begin{array}{c}\mathrm{N} \\
\text { F-stat. } \\
\text { P-value }\end{array}$ & $\begin{array}{l}18750 \\
1.775 \\
0.183 \\
\end{array}$ & $\begin{array}{c}3834 \\
3.698 \\
0.0545 \\
\end{array}$ & $\begin{array}{c}3390 \\
8.395 \\
0.00379 \\
\end{array}$ & $\begin{array}{c}1373 \\
19.92 \\
0.00000872 \\
\end{array}$ & $\begin{array}{c}1373 \\
9.082 \\
0.00263 \\
\end{array}$ \\
\hline
\end{tabular}

Standard errors in parentheses. Columns report group averages for variable indicated in column header by subgroups as denoted in rows. Column 1 presents average Leave vote intention among regular vs. occasional voters (excluding undecided voters) and draws on the full sample. Columns 2 to 5 provide evidence on the subgroup of occasional voters only. Column 2 presents average share of resondents with very high turnout intention among occasional voters with Leave vs. Remain vote intention. Column 3 mirrors the analysis of column 2 for very high turnout intention. Column 4 reports the share of respondents with a very high turnout intention among occasional voters who see sovereignty/immigration vs. another issue as 'most important' for their Referendum decision. Column 5 mirros the analysis of column 4 with economiy as 'most important' vs. another issue. Column 4 and 5 draw only on voters who gave a reason that could be categorized by the BES. Bottom two rows show F-statistic and corresponding p-values for a Wald test on difference between the column averages. BES survey weights for Great Britain used.

allows a test in this regard: The survey was rolled out daily, beginning 48 days prior to the referendum. We identify voters leaning towards Leave with a self-reported 2015 General Election vote for Ukip. We then contrast '(very) high' turnout intention for Leave vs. Remain-leaning respondents over time. Figure 2 reports a margins plot on whether Ukip supporters were more likely to report a '(very) high' turnout intention with proximity to election day. An important feature of this comparison is that party- and time-constant confounders are implicitly controlled for (e.g. overreporting). Time seems to play a role for the mobilization of (latent) Leave supporters. 48 days before the referendum, there was no difference between past Ukip and other party supporters in turnout likelihood. Just before the referendum, however, this was significantly different from zero: Ukip supporters are predicted to be two percentage points more likely to turn out (note that confidence intervals 
Figure 2: Difference in predicted probability of turnout between past Ukip and 'other party' supporters in the 12 pre-referendum weeks

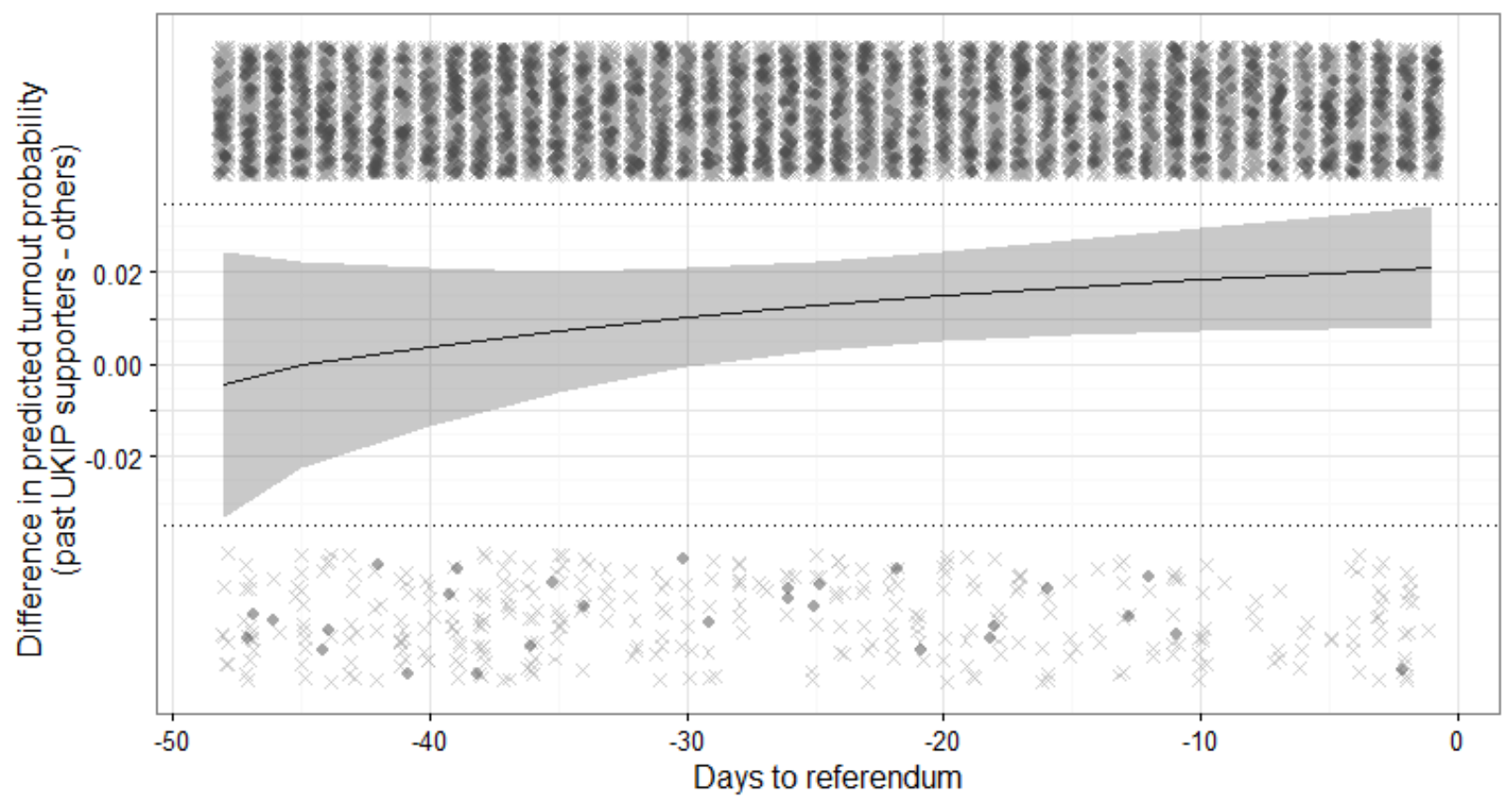

Average marginal effects from a binary logistic regression of Ukip support at the 2015 general election, date of response (1-48 days before referendum) and an interaction term on self-reported turnout intention ('fairly'/'very likely'). BES survey weights for Great Britain used. 95\% confidence intervals shown. Weighted $\mathrm{N}=12,551$. Controls for socio-demographics included (comp. Appendix TableA.13. Model 2). Strips indicate distribution of turnout intention variable (upper strip: ones; lower strip: zeros). Crosses represent 'other party' supporters $(\mathrm{N}=10,860 / \mathrm{N}=346)$, circles Ukip-supporters $(\mathrm{N}=1,402 / \mathrm{N}=28)$.

overlap). These results hold with and without inclusion of a broad set of socio-demographic control variables (see Appendix Section A.6).

To provide further evidence on S2, we now turn to the left-hand side of eq. (4), and assess whether elements of the voting reward function are likely correlated with referendum preferences among occasional voters.

A first step is to correlate self-reported Leave/Remain preferences, turnout intention and interest in the referendum among occasional voters. Table 3 shows that occasional voters that identify as Leave-supporters report both higher interest in the referendum (column 2) and see themselves as more likely to turn out (column 3) (results significant on the 5\%-level).

In a second step, we look at electoral benefits more closely. Electoral benefits stem from either the B- or D-term (see eq. (3)). The higher these perceived benefits, the higher the participation likelihood of an (occasional) voter. While we cannot directly test for the Band D-term, Smith (2001) e.g. argues that higher saliency leads to a higher B-term and subsequently larger electoral participation. As well, understanding the D-term as an expressive element of voting (Aldrich and Jenke, 2018), a higher issue saliency would lend more weight 
to the D-term and any citizen whose ideal point is close to the policies offered on the ballot has a larger incentive to participate. From the BES-survey data we can again empirically differentiate occasional voters by their self-stated turnout intention and the issues they see as most important. We find that survey respondents that see sovereignty/immigration as most important to be much more likely to report a very high turnout intention. Conversely, among occasional voters that see economic aspects of Brexit as most important, turnout intention is substantially lower (see column 4 and 5 of Table 3). This links to findings of Clarke et al (2017, 209) who argue that based on the relative saliency of issues "Leavers were more motivated to vote than Remainers." Appendix Table A.12 shows that the associations reported in Table 3 also hold in logistic regressions when controlling for socio-demographic and political controls.

Overall, the survey evidence presented here supports the view that occasional voters did not lean towards Leave in general, but rather that occasional voters leaning towards Leave were more likely to turn out compared to occasional voters leaning towards Remain. This implies that the mobilization of occasional voters was likely lopsided with respect to Leave preferences.

\section{Conclusion}

This paper analyses the role of turnout in the United Kingdom European Union membership ('Brexit') referendum. For this, we draw on an instrumental variables approach where rainfall affects voting costs and hence the participation decision. We show that rainfall is significantly and negatively related to turnout, and that voters marginal to rainfall (i.e. voting only in good weather) were predominantly supporting Leave.

We estimate that an increase in turnout of one percentage points relative to the European Parliament turnout baseline leads to an increase in the Leave vote share of about 0.75 percentage points. Our results imply that occasional voters that participated in the referendum were heavily leaning towards Leave. Survey evidence supports this interpretation and indicates that among the occasional voter population, mobilization was lopsided and Leave-leaning citizens were more likely to turn out.

These results might not have been expected given the predominant hypothesis in the literature that turnout benefits left-wing positions and parties (Tingsten, 1937). As well in Great Britain, earlier research pointed to an advantage for leftist positions with increasing turnout (McAllister and Mughan, 1986; Fisher, 2007). The political left in Great Britain in tendency supported Remain. As it has been argued that partisan orientations are an important cue for voters in referendums, particularly even in case of diverging partisan 
orientation and issue-specific attitudes (Selb et al, 2009), this would lead to the expectation that increases in turnout are related to support for Remain as well. That this is not the case highlights that referendums might follow a distinct logic beyond the traditional relationship of turnout and partisan support. The focus of the Brexit debate on not only economic aspects of EU membership but as well cultural factors (Inglehart and Norris, 2018) might have transcended the traditional left-right-distinction.

In interpreting the results, it is important to note that the IV approach used here assumes that rainfall had no direct effect on vote choice. Several recent studies raise the concern that rainfall could have such a direct effect. The literature argues e.g. that rainfall could work via psychological channels and affect the mood of voters, making them less risk averse ${ }^{17}$ Meier et al (2019) argue that rainfall induces voting for the status quo. Similarly, Bassi (2019) shows that low-risk candidates receive relatively more votes in bad weather and Horiuchi and Kang (2018) find that in the US Republicans, as most likely choice of risk-averse voters, see vote increases during bad weather. For our study, a direct psychological effect would imply that under good weather conditions (with better mood) voters were more likely to choose Leave as deviation from the status quo. In our estimations, the wide confidence interval of the preference gap would e.g. be consistent with this perspective. It is therefore possible that a direct effect is at work as well. Leslie and Arl (2018) provide explicit evidence in this regard. Note however that both Leslie and Arl (2018) and Horiuchi and Kang (2018) find that the main effect of rainfall still works through turnout.

In a broader picture our results emphasise a theoretical perspective where increases in turnout from a low baseline likely lead to more volatile outcomes (Hansford and Gomez, 2010). Future research could track more closely two specific mechanisms that drive this volatility. The population of interest would be occasional voters and how heterogeneous their propensity to turn out for a given elections is. In the Brexit example, negative voting (Fiorina and Shepsle, 1989) could be one part of the story, if opposition to the issue at stake (i.e. EU membership) lends itself more easily to mobilisation efforts compared to approval. Another perspective is given by the theory of expressive voting (Aldrich and Jenke, 2018): If one camp can more easily draw on an emotionalized debate (e.g. in our case Leave and sovereignty), the issue at stake lends itself more to a logic of expressive voting for this camp, which might be particularly relevant to explain heterogeneity in the mobilization of low-propensity voters.

Overall, the results add to a growing recent literature arguing that turnout is critical

\footnotetext{
${ }^{17}$ Note that the psychological literature is mixed in this regard with prominent findings of null, marginal or contingent effects of weather conditions on mood (Huibers et al, 2010, Keller et al, 2005; Denissen et al, 2008).
} 
to understand electoral outcomes and policy choice in democracies, and even more so in single-issue referendums when partisan attachements are weak. While parts of the literature highlight that increases in turnout lead to policy that is likely in line with median citizen preferences (e.g. Bechtel et al, 2016), others argue that average information levels and thus the quality of vote choice might deteriorate with higher turnout of low propensity voters (Schmid, 2015). Our findings emphasise that mobilisation of low-propensity voters can be lopsided - but it remains open whether under these conditions the increase in turnout leads to an alignment of median voter preferences with median citizen preferences or not. 


\section{References}

Aldrich JH, Jenke L (2018) Turnout and the Calculus of Voting: Recent Advances and Prospects for Integration with Theories of Campaigns and Elections. In: Fisher J, et al (eds) Routledge Handbook of Voting Behaviour and Public Opinion, Routledge, Abingdon, New York, chap 7, pp 83-95

Angrist JD, Pischke JS (2009) Mostly Harmless Econometrics: An Empiricist's Companion. Princeton University Press, Princeton

Arnold F, Freier R (2016) Only Conservatives Are Voting in the Rain: Evidence From German Local and State Elections. Electoral Studies 41:2016-221

Arnorsson A, Zoega G (2018) On the causes of Brexit. European Journal of Political Economy $55: 301-323$

Bassi A (2019) Weather, Risk, and Voting: An Experimental Analysis of the Effect of Weather on Vote Choice. Journal of Experimental Political Science 6(1):17-32

Bechtel MM, Hangartner D, Schmid L (2016) Does Compulsory Voting Increase Support for Redistributive Policy? American Journal of Political Science 60(3):752-767

Becker SO, Fetzer T, Novy D (2017) Who Voted for Brexit? A Comprehensive District-Level Analysis. Economic Policy 32(92):601-650

Berinsky AJ (2005) The Perverse Consequences of Electoral Reform in the United States. American Politics Research 33(4):471-491

Biggers DR (2011) When Ballot Issues Matter: Social Issue Ballot Measures and Their Impact on Turnout. Political Behavior 33(1):3-25

Birch S (2016) Our New Voters: Brexit, Political Mobilisation and the Emerging Electoral Cleavage. Juncture 23(2):107-110

Campbell DE, Monson JQ (2008) The religion card: Gay marriage and the 2004 presidential election. Public Opinion Quarterly 72(3):399-419

Cepaluni G, Hidalgo FD (2016) Compulsory Voting Can Increase Political Inequality: Evidence from Brazil. Political Analysis 24(2):273-280

Clarke HD, Goodwin M, Whiteley P (2017) Why Britain Voted for Brexit: An IndividualLevel Analysis of the 2016 Referendum Vote. Parliamentary Affairs 70(3):439-464

Cooperman AD (2017) Randomization inference with rainfall data. Political Analysis $25(3): 277-288$

Cox GW (1997) Making Votes Count: Strategic Coordination in the World's Electoral Systems, vol 7. Cambridge University Press, New York 
Denissen JJA, Butalid L, Penke L, Van Aken MAG (2008) The effects of weather on daily mood: a multilevel approach. Emotion 8(5):662

Evans G, Menon A (2017) Brexit and British politics. John Wiley \& Sons

Ferwerda J (2014) Electoral consequences of declining participation: A natural experiment in Austria. Electoral Studies 35:242-252

Finseraas H, Vernby K (2014) A mixed blessing for the left? Early voting, turnout and election outcomes in Norway. Electoral Studies 33:278-291

Fiorina MP, Shepsle KA (1989) Is Negative Voting an Artifact? American Journal of Political Science 33(2):423-439

Fisher SD (2007) (Change In) Turnout and (Change In) the Left Share of the Vote. Electoral Studies 26(3):598-611

Fowler A (2013) Electoral and Policy Consequences of Voter Turnout: Evidence from Compulsory Voting in Australia. Quarterly Journal of Political Science 8(2):159-182

Fowler A (2015) Regular Voters, Marginal Voters and the Electoral Effects of Turnout. Political Science Research and Methods 3(2):205-219

Goodwin M, Milazzo C (2017) Taking Back Control? Investigating the Role of Immigration in the 2016 Vote for Brexit. The British Journal of Politics and International Relations 19(3):450-464

Goodwin MJ, Heath O (2016) The 2016 Referendum, Brexit and the Left Behind: An Aggregate-level Analysis of the Result. The Political Quarterly 87(3):323-332

Hansford TG, Gomez BT (2010) Estimating the Electoral Effects of Voter Turnout. American Political Science Review 104(02):268-288

Hobolt SB, Tilley JR (2014) Blaming Europe? Responsibility Without Accountability in the European Union. Oxford Univ. Press, Oxford

Hodler R, Luechinger S, Stutzer A (2015) The effects of voting costs on the democratic process and public finances. American Economic Journal: Economic Policy 7(1):141-171

Horiuchi Y, Kang WC (2018) Why Should the Republicans Pray for Rain? Electoral Consequences of Rainfall Revisited. American Politics Research 46(5):869-889

Huibers MJ, de Graaf LE, Peeters FP, Arntz A (2010) Does the weather make us sad? Meteorological determinants of mood and depression in the general population. Psychiatry Research 180(2-3):143-146

Inglehart RF, Norris P (2018) Cultural backlash: Trump, Brexit, and authoritarian populism. Cambridge Univ. Pr. 
Johnston R, Pattie C (2006) Putting Voters in their Place: Geography and Elections in Great Britain. Oxford University Press, Oxford [a.o.]

Johnston R, Pattie C, Manley D (2017) Britain's Changed Electoral Map in and Beyond 2015: The Importance of Geography. The Geographical Journal 183(1):58-70

Keller MC, Fredrickson BL, Ybarra O, Côté S, Johnson K, Mikels J, Conway A, Wager T (2005) A warm heart and a clear head: The contingent effects of weather on mood and cognition. Psychological science 16(9):724-731

Lechner M (2011) The Estimation of Causal Effects by Difference-in-Difference Methods. Foundations and Trends in Econometrics 4(3):165-224

Leininger A, Heyne L (2017) How Representative Are Referendums? Evidence From 20 Years of Swiss Referendums. Electoral Studies 48:84-97

Leslie PA, Arı B (2018) Could rainfall have swung the result of the Brexit referendum? Political Geography 65:134-142

Lijphart A (1997) Unequal Participation: Democracy's Unresolved Dilemma. The American Political Science Review 91(1):1-14

Manley D, Jones K, Johnston R (2017) The geography of Brexit What geography? Modelling and predicting the outcome across 380 local authorities. Local Economy 32(3):183-203

McAllister I, Mughan A (1986) Differential Turnout and Party Advantage in British General Elections, 1964-83. Electoral Studies 5(2):143-152

Meier AN, Schmid L, Stutzer A (2019) Rain, emotions and voting for the status quo. European Economic Review 119(10350):434-451

Potrafke N, Roesel F (2018) Opening hours of polling stations and voter turnout: Evidence from a natural experiment. Review of International Organizations pp 1-31

Qvortrup M (2016) Referendums on Membership and European Integration 19722015. Political Quarterly 87(1):1-8

Riker WH, Ordeshook PC (1968) A Theory of the Calculus of Voting. American Political Science Review 62(01):25-42

Rodden J (2010) The Geographic Distribution of Political Preferences. Annual Review of Political Science 13(1):321-340

Schmid L (2015) Concurrent Elections, the Calculus of Voting, and Political Decisions. University of St Gallen, mimeo

Selb P, Kriesi H, Hänggli R, Marr M (2009) Partisan Choices in a Direct-democratic Campaign. European Political Science Review 1(1):155-172 
Smith MA (2001) The Contingent Effects of Ballot Initiatives and Candidate Races on Turnout. American Journal of Political Science 45(3):700

Tingsten H (1937) Political Behavior: Studies in Election Statistics. P. S. King and Son, London

Tobler WR (1970) A Computer Movie Simulating Urban Growth in the Detroit Region. Economic Geography 46:234-240

Treib O (2014) The Voter Says No, but Nobody Listens: Causes and Consequences of the Eurosceptic vote in the 2014 European Elections. Journal of European Public Policy 21(1):1-14

Zhang A (2018) New Findings on Key Factors Influencing the UK's Referendum on Leaving the EU. World Development 102:304-314 


\section{A Online Appendix for 'Turning out to turn down the EU: The mobilisation of occasional voters and Brexit'}

\section{A.1 Literature on the link between turnout and the Brexit deci- sion}

Differential turnout is one major explanation of the Brexit vote. As Evans and Menon (2017, 33-35) discuss, electoral participation declined in the pre-referendum decades to an average of $63 \%$. Importantly, they highlight that this decline was uneven across social classes and education groups, leading to a large participation gap between voters of different sociodemographic backgrounds. If the increase in turnout with the referendum is similarly unequal across socio-demographic strata this would imply that on the one hand the participation gap closed, but on the other hand that the turnout increase was likely consequential for the referendum outcome. Evans and Menon (2017, 80f.) highlight particularly that the gap between high and low educated voters closed. As class and education are one important predictor of Leave support, the increase in turnout could be related to Leave support. However, as noted by others (Manley et al, 2017; Dorling et al, 2016; Birch, 2016), the participation gap is as well highly prevalent with respect to young vs. old voters as young age predicts Remain support, they conclude that an increase in turnout should be related to Remain support. Consequently, empirical findings are mixed. Most published research reports a strong association between turnout and the Leave vote. Prominently, Zhang (2018) shows that turnout is strongly and positively related to the Leave vote in England and Wales (but not Scotland and Northern Ireland). He estimates that, had overall turnout increased by 7 percentage points less in England and Wales, a Remain victory would have been the likely outcome. Though not explicitely linking turnout to Leave support, Becker et al (2017, 637) analyzes determinants of referendum turnout and argues that "turnout was lower in those areas with a higher potential in favour of Remain ${ }^{18}$ While criticized on methodical ground (Johnston et al, 2018), their general picture is supported by post-referendum survey data, where those leaning towards Remain reported lower turnout (Swales, 2016). Backing these findings and based on the differential success of the Leave and the Remain campaign as well as the saliency of issues, Clarke et al (2017, 209) e.g. argue "that Leavers were more motivated to vote than Remainers [...] is a plausible idea." However, other researchers (Manley et al, 2017) report an association between higher turnout and Remain. Their estimates imply that turnout was negatively related to the Leave vote and corrobate this finding by analyzing voter registrations - voter registrations increased substantially where Remain performed well in the referendum. Goodwin and Heath $(2016,326)$ add a note of caution to the interpretation of these associations: While "high turnout might have helped the Leave vote, as turnout was generally higher in more pro-Leave areas [] we should treat these results with caution, as it does not necessarily follow that it was Leave voters who were disproportionately more likely to turn out and vote. There could also have been a 'counter-mobilisation effect' whereby

\footnotetext{
${ }^{18}$ Among others, they note that election day rainfall and subsequent train cancellations led to a decrease in turnout, although they do not find a direct relation to electoral outcomes.
} 
Remain supporters were more likely to vote when they were motivated by the awareness that Leave was popular in their local area." Finally, the reported associations in turnout levels and the Leave vote also leave open the question how the increase in turnout observed with the referendum was related to Leave support. On the one hand, turnout in prior elections is strongly related to referendum turnout and hence the Leave vote (Goodwin and Heath, 2016). On the other hand, mobilizing factors are unevenly distributed across the UK. E.g. (Fetzer, 2018; Alabrese and Fetzer, 2018) make the argument that austerity measures are related to the Brexit vote and that voters affected by austerity measures voiced their protest via the Leave decision. They relate this to the possibility of differential mobilization in areas with high and low levels of austerity. Other observers note that the preferences of abstainers and especially the age-turnout gradient likely affected results, with non-voters, especially young non-voters, likely being pro-remain on average (see e.g., Low (2016); Eichengreen et al (2018)). All in all, this literature implies that turnout is an important factor in explaining the Brexit vote and for referendum outcomes more generally. As emphasized by Clarke et al (2017, 210), simulations based on stated preferences of non-voters in survey data indicate that the outcome of the referendum could have gone either way with full participation. They argue that the odds of a Remain victory in one million uneqicoval-turnout-referendums are close to 2:1. However, in a real-world scenario with turnout below $100 \%$ these odds will to a large extent depend on the degree of voter mobilization and whether voters who latently support the one or the other referendum camp have differential participation incentives. This makes it important to better understand the role of turnout for electoral outcomes.

\section{A.2 Summary statistics, balance and placebo tests}

This appendix section provides background for the research design as discussed in the research design section in the main text.

First of all, Appendix Table A.1 provides a simple descriptive summary of the dependent, independent and control variables used in the analyses.

Second, Appendix Table A.2 provides t-tests on the means of co-determinants of turnout and Leave vote for all local authorities within the control (no rain) and treatment group (rain $>0 \mathrm{~mm}$ ). First, one can see from the comparison that treatment and control group differ with respect to several socio-economic control variables (share of population over 60, unemployment, population density, labor market structure, migrant share, ethnic white share, region). This is to be expected as the rainfall event predominantly hit the south and east of England as well as some areas of Scotland and Northern Ireland and it is plausible that these specific areas are not directly comparable to an average local authority from the rest of the UK. Appendix Table A.2 confirms that such correlations exit, which therefore demands a research design that can take these pre-existing differences in socio-economic covariates into account. This is why we are 1) explicitly controlling for observables and 2) are drawing on first differences to implicitly control for level differences. Second, one can see from comparing the differences-in-means in the full (left panel) and adjacent sample (right panel) that for most of these covariates the difference in group means becomes smaller in the adjacent sample: Among the significant associations on the left hand, the difference in the share of unemployed and in the trend in unemployment shrinks to almost zero, the difference in high skilled labour is reduced (though remains significant), and the difference in 2014 European 
Election Ukip shares halves (and becomes insignificant). All these changes support the argument that with the adjacent sample we are increasing the ex-ante comparability of the treated and control group. Note, however, that some covariate-differences barely change (e.g. population density, which is larger in the treatment group, share in low-skilled labour, which is larger in the control group, the share in the ethnic white population, which is larger in the control group and the share in the migrant population, smaller in the control group) and for one covariate the difference increases (share of population over 60). Still, the overall picture implies that within the adjacent sample treatment and control group are more comparable (cf. below and Appendix Figure A.1 for additional evidence on this argument). Given that differences remain, controlling for these observable differences is an important feature of the reserach design, as is a strategy relying on first differences to implicitly control for remaining imbalance between the treatment and control group.

Third, Appendix Figure A.1 supports the assumption that a geographically proximate sample (the "adjacent sample" ) improves the causal interpretation of the estimated coefficients. To ascertain that this is a sensible strategy we proceed as follows: We distinguish the full sample from the adjacent sample. We then regress rainfall on various socio-demographic controls that are likely related to turnout and Leave share. With a true random event, we would expect a uniform distribution of p-values - given the geographical clustering of our case, this is unlikely, of course, but we can still assess whether the adjacent sample likely improves the inference. Appendix Figure A.1 then reports a Q-Q plot of empirically observed p-values against this theoretically ideal uniform distribution. It has two main conclusions: On the one hand, there are substantial correlations between observable local authority characteristics and rainfall. This warrants an empirical strategy where we control for the said variables. On the other hand, the statistical strength of these correlations shrinks substantially with the adjacent sample: Then, only two variables are statistically related to rainfall on the $5 \%$-level, four on the $10 \%$-level, compared to five on the $5 \%$ - and ten on the $10 \%$ level for the full sample. As well, the maximum distance to the uniform distribution is still substantial with 0.45 , but decreases by $27 \%$ for the adjacent sample.

Fourth, Appendix Figure A.2 depicts the descriptive trend of Ukip/Leave support in local authorities with/without rainfall over three elections. This is to support the argument that a differencing strategy is feasible. As can be seen, in the pre-treatment period, i.e. inbetween the 2009 and 2014 European Elections, the dependent variable (Ukip support) is following a parallel trend in regions with/without rain. Differences in the trend are discernible for 2016.

Fifth, while it can in principle not be tested whether rainfall is exogenous to turnout in the case at hand, we can find indications for this in placebo tests: As suggested by Angrist and Pischke (2009), we conduct a placebo test on whether referendum day rainfall is related to unaffected outcomes. For this, Appendix Table A.3 reports regressions of election day rainfall on the difference in pre-treatment postal voting applications and pre-treatment postal ballot turnout. Regressions follow the set-up of Table 1. The argument is that structural shifts in participation patterns should extend to postal voters as well, while rainfall could not affect the postal vote participation decision. The (placebo) association of the trend in both postal voting registrations (i.e. envelops issued over total electorate) and postal ballot turnout (i.e. envelopes returned over envelopes issued) is substantially small and insignificantly related to rainfall on election day. 
Table A.1: Summary statistics for variables used in the analysis

\begin{tabular}{lccc|ccc}
\hline \hline & \multicolumn{3}{c|}{ Full sample } & \multicolumn{3}{c}{ Adjacent sample } \\
& mean & min & max & mean & min & max \\
\hline Turnout in \% & 73.73 & 56.25 & 83.57 & 75.13 & 59.25 & 83.57 \\
Turnout for 2014 EE & 35.86 & 23.74 & 51.94 & 36.61 & 23.74 & 51.77 \\
2016 Referendum TO - 2014 EE TO & 37.87 & 10.75 & 49.24 & 38.52 & 12.83 & 49.24 \\
Average election day rainfall (mm) & 3.13 & 0.00 & 42.20 & 4.29 & 0.00 & 42.20 \\
Share of population aged 20-30 & 12.54 & 7.62 & 27.93 & 12.58 & 7.62 & 27.93 \\
Share of population aged 60+ & 23.96 & 8.44 & 38.05 & 23.78 & 8.44 & 38.05 \\
Share of unemployed & 1.58 & 0.30 & 4.70 & 1.31 & 0.30 & 4.20 \\
Change in 2016 unemployment share & -0.07 & -0.70 & 0.80 & -0.09 & -0.70 & 0.30 \\
Population density & 14.77 & 0.10 & 138.70 & 17.16 & 0.30 & 138.70 \\
Population size (log) & 11.82 & 7.70 & 14.41 & 11.79 & 7.70 & 13.89 \\
Share of employed in high skilled labor & 10.90 & 6.10 & 23.30 & 11.55 & 6.60 & 23.30 \\
Share of employed in low skilled labor & 11.08 & 3.60 & 21.10 & 10.82 & 3.60 & 21.10 \\
Share of migrants from outside UK & 0.97 & 0.18 & 6.45 & 1.08 & 0.22 & 6.45 \\
Share of ethnic group white & 90.33 & 28.82 & 99.26 & 88.57 & 28.82 & 98.82 \\
Country/region==England & 0.77 & 0.00 & 1.00 & 0.88 & 0.00 & 1.00 \\
Country/region==Wales & 0.06 & 0.00 & 1.00 & 0.00 & 0.00 & 0.00 \\
Country/region==Scotland & 0.08 & 0.00 & 1.00 & 0.00 & 0.00 & 0.00 \\
Country/region==London & 0.09 & 0.00 & 1.00 & 0.12 & 0.00 & 1.00 \\
Country/region==Northern Ireland & 0.00 & 0.00 & 1.00 & 0.00 & 0.00 & 0.00 \\
Ukip share in EE & 29.10 & 3.93 & 51.58 & 31.43 & 4.90 & 51.58 \\
Leave in \% & 53.12 & 21.38 & 75.56 & 54.08 & 21.38 & 75.56 \\
Diff in 2016 Leave - 2014 Ukip share & 24.01 & 10.95 & 40.32 & 22.66 & 10.95 & 38.82 \\
\hline Observations & 381 & & & 275 & & \\
\hline \hline
\end{tabular}

Table displays summary statistics for all dependent, independent and control variables used in the analyses. The 'mean' of indicators variables for country/region denotes the share of local authorities from said country/region. Full sample: all observations from the UK; adjacent sample: English regions with at least one local authority experiencing rainfall. 
Table A.2: T-test of mean difference for control variables used in the analysis between local authorities experiencing and not experiencing any rainfall on referendum day and for the full (left panel) and the adjacent sample (right panel)

\begin{tabular}{|c|c|c|c|c|c|c|}
\hline & \multicolumn{3}{|c|}{ Full sample } & \multicolumn{3}{|c|}{ Adjacent sample } \\
\hline & $\begin{array}{c}\text { Control: } \\
\text { No rain } \\
\text { Group mean }\end{array}$ & $\begin{array}{c}\text { Treated: } \\
\text { Rain }>0 \mathrm{~mm} \\
\text { Group mean }\end{array}$ & $\begin{array}{l}\text { Diff-In- } \\
\text { Means } \\
\text { (se) }\end{array}$ & $\begin{array}{c}\text { Control: } \\
\text { No rain } \\
\text { Group mean }\end{array}$ & $\begin{array}{c}\text { Treated: } \\
\text { Rain }>0 \mathrm{~mm} \\
\text { Group mean }\end{array}$ & $\begin{array}{l}\text { Diff-In- } \\
\text { Means } \\
\text { (se) }\end{array}$ \\
\hline Share of population aged $20-30$ & 12.32 & 12.72 & $\begin{array}{c}-0.40 \\
(0.37)\end{array}$ & 12.08 & 12.78 & $\begin{array}{l}-0.70 \\
(0.51)\end{array}$ \\
\hline Share of population aged $60+$ & 24.92 & 23.17 & $\begin{array}{c}1.75^{* * *} \\
(0.51)\end{array}$ & 25.56 & 23.07 & $\begin{array}{c}2.49^{* * *} \\
(0.72)\end{array}$ \\
\hline Share of unemployed & 1.86 & 1.34 & $\begin{array}{c}0.52^{* * *} \\
(0.09)\end{array}$ & 1.30 & 1.31 & $\begin{array}{l}-0.01 \\
(0.09)\end{array}$ \\
\hline Change in 2016 unemployment share & -0.04 & -0.09 & $\begin{array}{c}0.05^{* * *} \\
(0.02)\end{array}$ & -0.10 & -0.08 & $\begin{array}{l}-0.02 \\
(0.02)\end{array}$ \\
\hline Population density & 9.52 & 19.09 & $\begin{array}{c}-9.57^{* * *} \\
(2.26)\end{array}$ & 9.82 & 20.07 & $\begin{array}{c}-10.24^{* * *} \\
(3.33)\end{array}$ \\
\hline Population size $(\log )$ & 11.82 & 11.82 & $\begin{array}{l}-0.00 \\
(0.06)\end{array}$ & 11.76 & 11.81 & $\begin{array}{l}-0.05 \\
(0.08)\end{array}$ \\
\hline Share of employed in high skilled labor & 9.96 & 11.67 & $\begin{array}{c}-1.71^{* * *} \\
(0.24)\end{array}$ & 10.81 & 11.85 & $\begin{array}{c}-1.04^{* * *} \\
(0.32)\end{array}$ \\
\hline Share of employed in low skilled labor & 11.81 & 10.47 & $\begin{array}{c}1.34^{* * *} \\
(0.24)\end{array}$ & 11.87 & 10.41 & $\begin{array}{c}1.46^{* * *} \\
(0.35)\end{array}$ \\
\hline Share of migrants from outside UK & 0.71 & 1.18 & $\begin{array}{c}-0.47^{* * *} \\
(0.09)\end{array}$ & 0.77 & 1.20 & $\begin{array}{c}-0.44^{* * *} \\
(0.12)\end{array}$ \\
\hline Share of ethnic group white & 93.93 & 87.36 & $\begin{array}{c}6.57^{* * *} \\
(1.22)\end{array}$ & 93.23 & 86.73 & $\begin{array}{c}6.50^{* * *} \\
(1.77)\end{array}$ \\
\hline Country $/$ region $==$ England & 0.75 & 0.78 & $\begin{array}{l}-0.03 \\
(0.04)\end{array}$ & 1.00 & 0.83 & $\begin{array}{c}0.17^{* * *} \\
(0.04)\end{array}$ \\
\hline Country $/$ region $==$ Wales & 0.13 & 0.00 & $\begin{array}{c}0.13^{* * *} \\
(0.02)\end{array}$ & 0.00 & 0.00 & $\begin{array}{c}0.00 \\
(0.00)\end{array}$ \\
\hline Country $/$ region $==$ Scotland & 0.12 & 0.05 & $\begin{array}{l}0.07^{* *} \\
(0.03)\end{array}$ & 0.00 & 0.00 & $\begin{array}{c}0.00 \\
(0.00)\end{array}$ \\
\hline Country $/$ region $==$ London & 0.00 & 0.16 & $\begin{array}{c}-0.16^{* * *} \\
(0.03)\end{array}$ & 0.00 & 0.17 & $\begin{array}{c}-0.17^{* * *} \\
(0.04)\end{array}$ \\
\hline Country $/$ region $==$ Northern Ireland & 0.00 & 0.00 & $\begin{array}{l}-0.00 \\
(0.01)\end{array}$ & 0.00 & 0.00 & $\begin{array}{c}0.00 \\
(0.00)\end{array}$ \\
\hline Ukip share in EE & 28.07 & 29.95 & $\begin{array}{l}-1.88^{*} \\
(0.97)\end{array}$ & 32.09 & 31.16 & $\begin{array}{c}0.92 \\
(1.14)\end{array}$ \\
\hline $\begin{array}{l}\text { N Control group } \\
\text { N Treatment group } \\
\text { Total Observations }\end{array}$ & $\begin{array}{l}172 \\
209 \\
381\end{array}$ & & & $\begin{array}{c}78 \\
197 \\
275\end{array}$ & & \\
\hline
\end{tabular}

Table displays means for control and treatment group local authorities and the corresponding t-test on a difference in means for all control variables used in the analyses. The left panel displays t-tests for the full sample of local authorities in the UK, the right panel for local authorities from regions with variation in rainfall. $* *(*, * * *)$ indicates $\mathrm{p}<0.05(0.1,0.01)$ 
Figure A.1: Associations of average rainfall with covariates in full and in adjacent sample

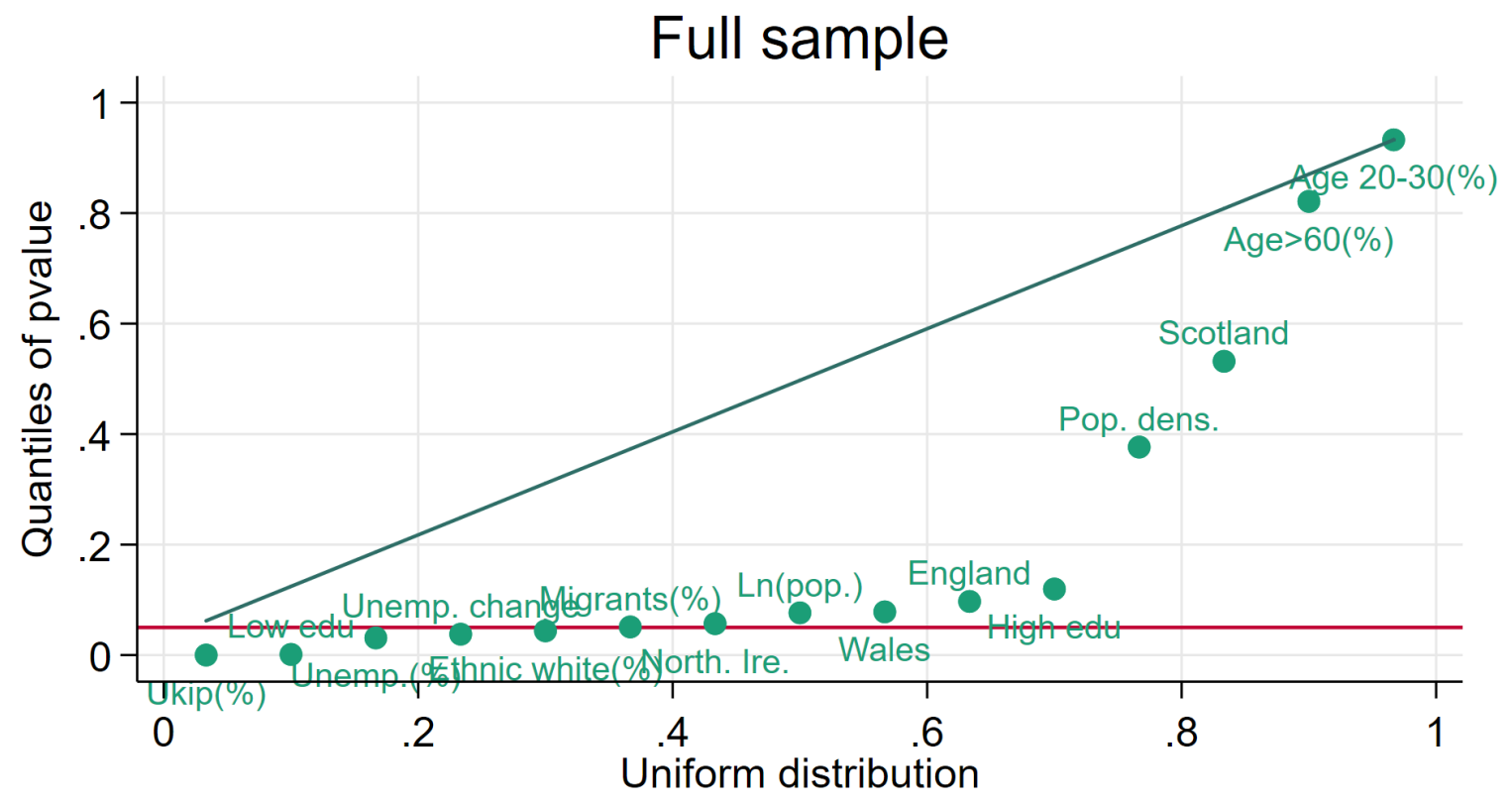

Adjacent sample

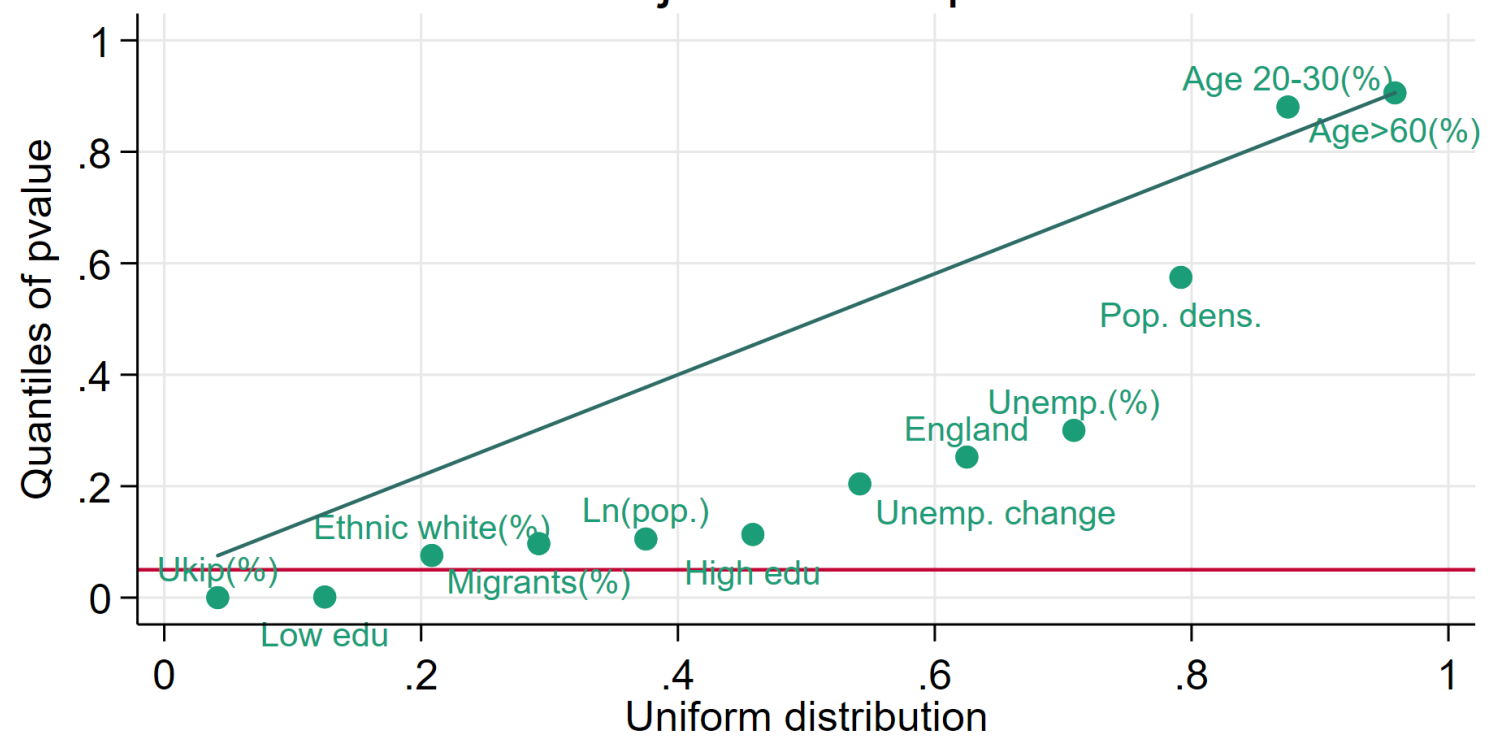

The figure displays a Q-Q-plot of observed p-values against a uniform distribution. P-values are derived from regressions of average rainfall on the marker label (controlling for all other variables displayed in the marker labels). The upper panel displays the distribution of p-values for the full sample of local authorities in the UK, the lower panel for local authorities from regions with variation in rainfall. 
Figure A.2: Descriptive trends of Ukip support (2009 and 2014 European Elections) and Leave support (2016 referendum) by local authorities (not) experiencing rainfall
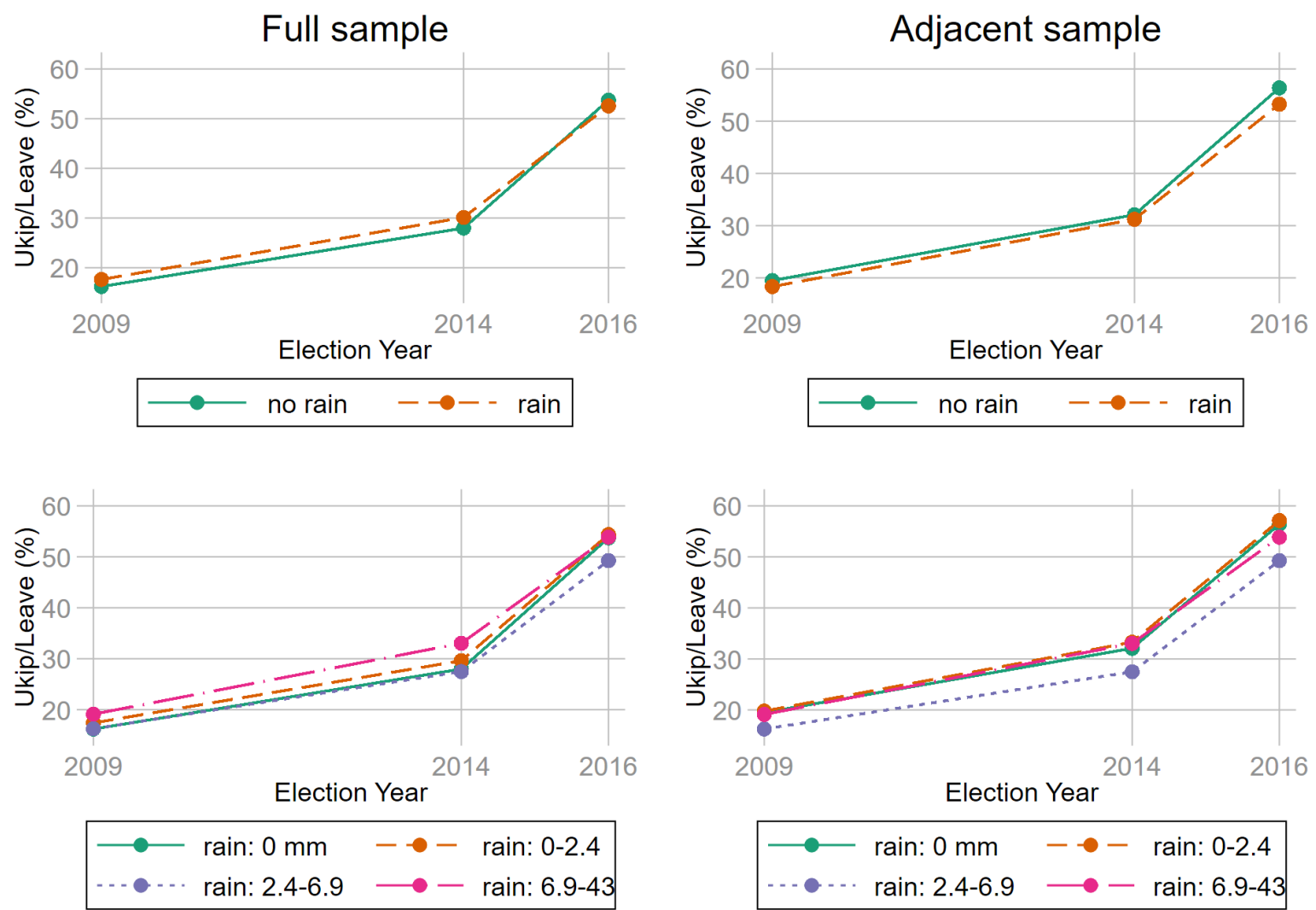

Election Year

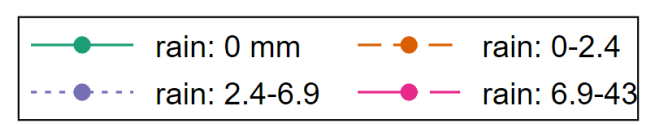

The figure displays average Leave/Ukip support in the 2009 and 2014 European Parlaiment Elections and the 2016 Brexit Referendum in local authorities of the UK by rainfall exposure. Upper panel splits rainfall by no and positive rainfall. Lower panel splits rainfall by no rainfall and terciles among local authorities with positive rain (in millimetres on election day). The left panel displays the distribution for the full sample of local authorities, the right panel for local authorities from regions with variation in rainfall. Total $\mathrm{N}$ equals 364, which is slightly lower than the 381 observations in the treatment period (4 local authorities from England and 13 local authorities from Wales could not be matched due to local authority mergers and splits). 
Table A.3: Placebo regressions on trend in postal ballot registration and turnout

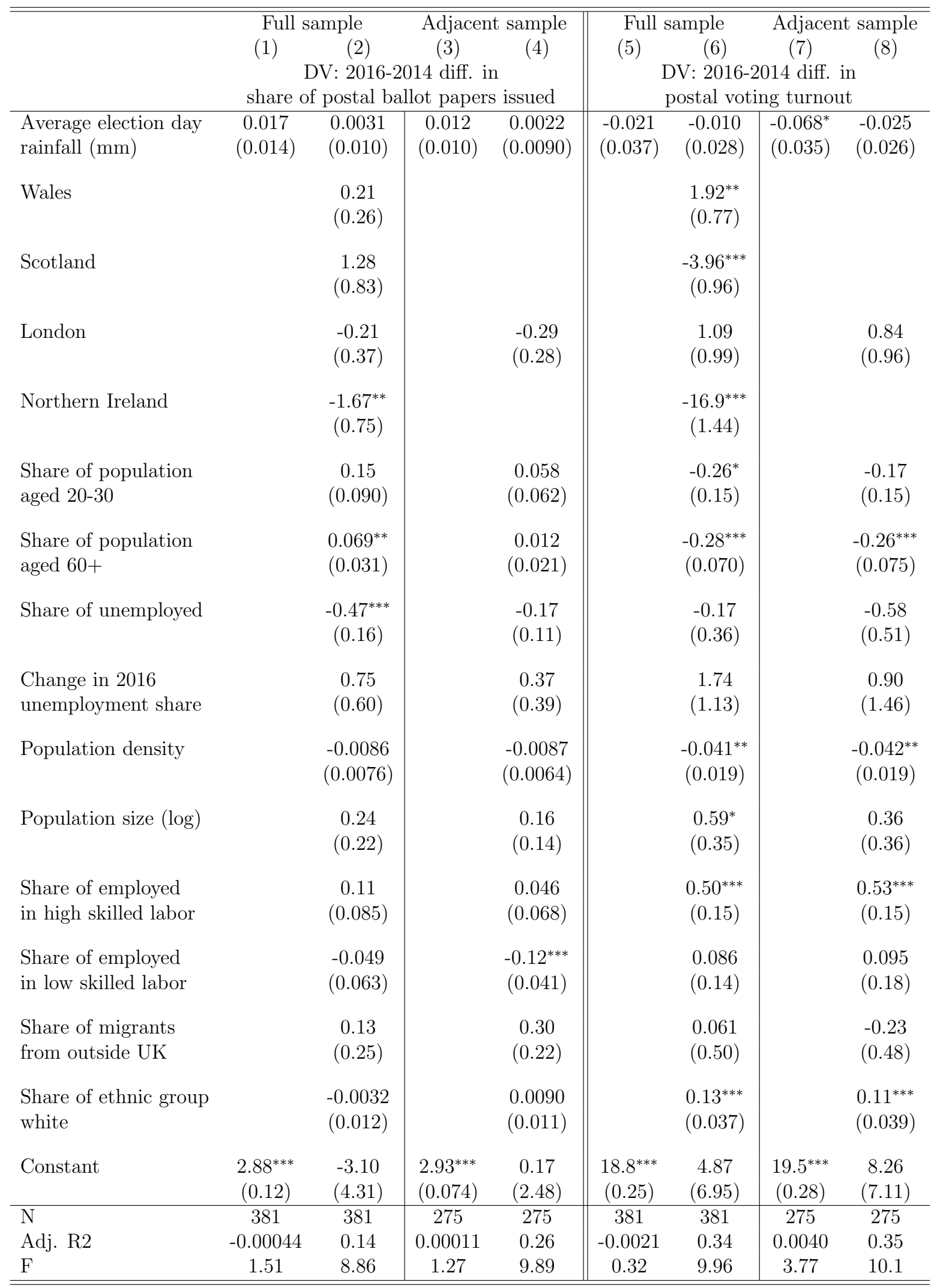

Table reports tests for the (placebo) effect of election day rainfall on the share of postal ballots issued and the share of postal ballot turnout.

$* *(*, * *)$ indicates $\mathrm{p}<0.05(0.1,0.01)$ 


\section{A.3 Full model display of tables in main text and OLS regressions of the turnout effect}

In the following we present two tables that display all coefficient for Tables 11 and 2 in the main text, where coefficient estimates for control variables were omitted for the sake of brevity (Appendix Tables A.4 and A.5). Subsequently, we present the OLS regressions referenced in the results section of the main text. Finally, we present the reduced form estimates (Appendix Table A.7) for completeness. 
Table A.4: Effect of election day rainfall (in $\mathrm{mm}$ ) on turnout - full results of Table 1

\begin{tabular}{|c|c|c|c|c|c|c|}
\hline & \multicolumn{6}{|c|}{ Dep. var.: 2016 Referendum - 2014 EE turnout } \\
\hline & \multicolumn{3}{|c|}{ Full sample } & \multicolumn{3}{|c|}{ Adjacent sample } \\
\hline & (1) & (2) & (3) & (4) & (5) & (6) \\
\hline Average election day rainfall $(\mathrm{mm})$ & $\begin{array}{l}-0.11^{* *} \\
(0.047)\end{array}$ & $\begin{array}{c}-0.071^{* *} \\
(0.028)\end{array}$ & $\begin{array}{c}-0.14^{* * *} \\
(0.030)\end{array}$ & $\begin{array}{l}-0.21^{* * *} \\
(0.048)\end{array}$ & $\begin{array}{c}-0.098^{* * *} \\
(0.026)\end{array}$ & $\begin{array}{c}-0.14^{* * *} \\
(0.028)\end{array}$ \\
\hline Wales & & $\begin{array}{l}1.08^{*} \\
(0.65)\end{array}$ & $\begin{array}{c}2.22^{* * *} \\
(0.60)\end{array}$ & & & \\
\hline Scotland & & $\begin{array}{c}-4.08^{* * *} \\
(1.10)\end{array}$ & $\begin{array}{c}0.46 \\
(1.40)\end{array}$ & & & \\
\hline London & & $\begin{array}{c}-2.44^{* *} \\
(0.99)\end{array}$ & $\begin{array}{c}-1.87^{* *} \\
(0.94)\end{array}$ & & $\begin{array}{c}-2.82^{* * *} \\
(0.97)\end{array}$ & $\begin{array}{c}-2.57^{* * *} \\
(0.93)\end{array}$ \\
\hline Northern Ireland & & $\begin{array}{c}-25.6^{* * *} \\
(1.25)\end{array}$ & $\begin{array}{c}-19.6^{* * *} \\
(1.58)\end{array}$ & & & \\
\hline Share of population aged $20-30$ & & $\begin{array}{c}-0.30^{* *} \\
(0.13)\end{array}$ & $\begin{array}{l}-0.15 \\
(0.14)\end{array}$ & & $\begin{array}{c}-0.29^{* *} \\
(0.14)\end{array}$ & $\begin{array}{l}-0.15 \\
(0.15)\end{array}$ \\
\hline Share of population aged $60+$ & & $\begin{array}{c}-0.23^{* * *} \\
(0.055)\end{array}$ & $\begin{array}{c}-0.24^{* * *} \\
(0.053)\end{array}$ & & $\begin{array}{c}-0.24^{* * *} \\
(0.054)\end{array}$ & $\begin{array}{c}-0.24^{* * *} \\
(0.052)\end{array}$ \\
\hline Share of unemployed & & $\begin{array}{c}-1.45^{* * *} \\
(0.30)\end{array}$ & $\begin{array}{c}-1.52^{* * *} \\
(0.29)\end{array}$ & & $\begin{array}{c}-1.02^{* * *} \\
(0.34)\end{array}$ & $\begin{array}{c}-1.35^{* * *} \\
(0.36)\end{array}$ \\
\hline Change in 2016 unemployment share & & $\begin{array}{c}0.71 \\
(1.06)\end{array}$ & $\begin{array}{c}0.67 \\
(1.01)\end{array}$ & & $\begin{array}{c}0.50 \\
(1.14)\end{array}$ & $\begin{array}{l}0.045 \\
(1.14)\end{array}$ \\
\hline Population density & & $\begin{array}{l}-0.021 \\
(0.015)\end{array}$ & $\begin{array}{l}-0.017 \\
(0.016)\end{array}$ & & $\begin{array}{l}-0.020 \\
(0.015)\end{array}$ & $\begin{array}{l}-0.017 \\
(0.015)\end{array}$ \\
\hline Population size (log) & & $\begin{array}{l}-0.029 \\
(0.34)\end{array}$ & $\begin{array}{l}-0.038 \\
(0.34)\end{array}$ & & $\begin{array}{l}-0.45 \\
(0.29)\end{array}$ & $\begin{array}{l}-0.39 \\
(0.28)\end{array}$ \\
\hline Share of employed in high skilled labor & & $\begin{array}{c}0.58^{* * *} \\
(0.13)\end{array}$ & $\begin{array}{c}0.65^{* * *} \\
(0.13)\end{array}$ & & $\begin{array}{c}0.48^{* * *} \\
(0.13)\end{array}$ & $\begin{array}{c}0.60^{* * *} \\
(0.13)\end{array}$ \\
\hline Share of employed in low skilled labor & & $\begin{array}{c}0.31^{* * *} \\
(0.12)\end{array}$ & $\begin{array}{c}0.19 \\
(0.11)\end{array}$ & & $\begin{array}{l}0.19^{*} \\
(0.11)\end{array}$ & $\begin{array}{c}0.13 \\
(0.11)\end{array}$ \\
\hline Share of migrants from outside UK & & $\begin{array}{l}-0.23 \\
(0.43)\end{array}$ & $\begin{array}{l}-0.20 \\
(0.42)\end{array}$ & & $\begin{array}{l}-0.56 \\
(0.41)\end{array}$ & $\begin{array}{l}-0.57 \\
(0.37)\end{array}$ \\
\hline Share of ethnic group white & & $\begin{array}{l}0.19^{* * * *} \\
(0.031)\end{array}$ & $\begin{array}{l}0.15^{* * *} \\
(0.031)\end{array}$ & & $\begin{array}{l}0.18^{* * *} \\
(0.031)\end{array}$ & $\begin{array}{l}0.14^{* * *} \\
(0.033)\end{array}$ \\
\hline Ukip share in EE & & & $\begin{array}{l}0.19^{* * *} \\
(0.033)\end{array}$ & & & $\begin{array}{l}0.15^{* * *} \\
(0.036)\end{array}$ \\
\hline Constant & $\begin{array}{c}38.2^{* * *} \\
(0.30)\end{array}$ & $\begin{array}{c}24.0^{* * *} \\
(7.36) \\
\end{array}$ & $\begin{array}{c}21.0^{* * *} \\
(7.10) \\
\end{array}$ & $\begin{array}{c}39.4^{* * *} \\
(0.33)\end{array}$ & $\begin{array}{c}33.2^{* * *} \\
(6.53)\end{array}$ & $\begin{array}{r}29.4^{* * *} \\
(6.28)\end{array}$ \\
\hline $\mathrm{N}$ & 381 & 381 & 381 & 275 & 275 & 275 \\
\hline r2_a & 0.0079 & 0.69 & 0.71 & 0.042 & 0.77 & 0.79 \\
\hline $\mathrm{F}$ & 5.84 & 46.7 & 44.8 & 19.2 & 53.4 & 47.8 \\
\hline
\end{tabular}

Table reports estimates of rainfall (in $\mathrm{mm}$ ) on difference in 2016 referendum to 2014 European Election turnout. Robust standard errors in parantheses. Models 1,2 and 4, 5 display the models 1,2 and 3, 4 of Table 1 in full. Models 3 and 6 include 2014 European Election Ukip vote as additional variable to provide the correct first stage (i.e. identical variable set) for model 2 and 4 of Table A.10 as used in Appendix Section A.4. Otherwise see notes to Table $1 . * *(* * * *)$ indicates $\mathrm{p}<0.05(0.1,0.01)$ 
Table A.5: Instrumental variable regression: Effect of turnout change on Leave vote/change - full results of Table 2

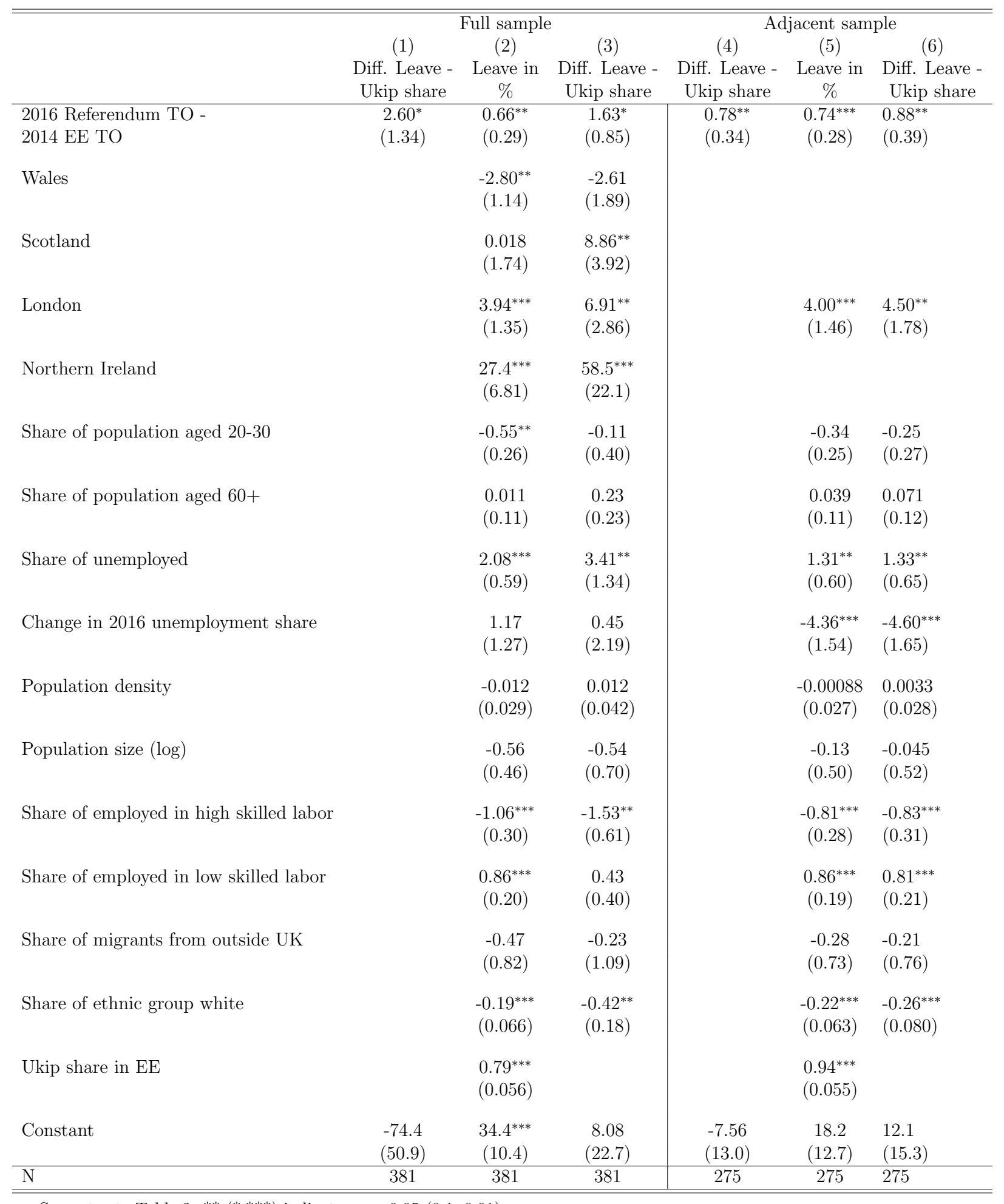

See notes to Table 2. ** $(*, * * *)$ indicates $\mathrm{p}<0.05(0.1,0.01)$ 
Table A.6: Non-instrumented association between turnout increase and Leave as in Table 2

\begin{tabular}{|c|c|c|c|c|c|c|}
\hline & \multicolumn{3}{|c|}{ Full sample } & \multicolumn{3}{|c|}{ Adjacent sample } \\
\hline & (1) & $(2)$ & $(3)$ & $(4)$ & $(5)$ & $(6)$ \\
\hline & $\begin{array}{l}\text { Diff. Leave - } \\
\text { Ukip share }\end{array}$ & $\begin{array}{c}\text { Leave in } \\
\%\end{array}$ & $\begin{array}{l}\text { Diff. Leave - } \\
\text { Ukip share }\end{array}$ & $\begin{array}{l}\text { Diff. Leave - } \\
\text { Ukip share }\end{array}$ & $\begin{array}{c}\text { Leave in } \\
\%\end{array}$ & $\begin{array}{c}\text { Diff. Leave - } \\
\text { Ukip share }\end{array}$ \\
\hline 2016 Referendum TO - 2014 EE TO & $\begin{array}{c}-0.28^{* * *} \\
(0.058)\end{array}$ & $\begin{array}{c}-0.098 \\
(0.065)\end{array}$ & $\begin{array}{l}-0.13^{* *} \\
(0.062)\end{array}$ & $\begin{array}{l}-0.17^{* *} \\
(0.074)\end{array}$ & $\begin{array}{r}-0.0077 \\
(0.078)\end{array}$ & $\begin{array}{l}0.00075 \\
(0.073)\end{array}$ \\
\hline Wales & & $\begin{array}{l}-1.02 \\
(0.77)\end{array}$ & $\begin{array}{l}-0.33 \\
(0.74)\end{array}$ & & & \\
\hline Scotland & & $\begin{array}{l}-0.014 \\
(1.28)\end{array}$ & $\begin{array}{l}2.13^{* *} \\
(1.03)\end{array}$ & & & \\
\hline London & & $\begin{array}{l}2.28^{* *} \\
(1.00)\end{array}$ & $\begin{array}{l}2.41^{* *} \\
(0.97)\end{array}$ & & $\begin{array}{l}1.88^{*} \\
(0.98)\end{array}$ & $\begin{array}{l}1.87^{*} \\
(0.99)\end{array}$ \\
\hline Northern Ireland & & $\begin{array}{c}11.2^{* * *} \\
(1.99)\end{array}$ & $\begin{array}{c}13.0^{* * *} \\
(1.98)\end{array}$ & & & \\
\hline Share of population aged $20-30$ & & $\begin{array}{c}-0.67^{* * *} \\
(0.20)\end{array}$ & $\begin{array}{c}-0.61^{* * *} \\
(0.19)\end{array}$ & & $\begin{array}{c}-0.46^{* *} \\
(0.19)\end{array}$ & $\begin{array}{l}-0.48^{* *} \\
(0.19)\end{array}$ \\
\hline Share of population aged $60+$ & & $\begin{array}{l}-0.18^{* *} \\
(0.069)\end{array}$ & $\begin{array}{c}-0.19^{* * *} \\
(0.069)\end{array}$ & & $\begin{array}{l}-0.15^{* *} \\
(0.064)\end{array}$ & $\begin{array}{l}-0.14^{* *} \\
(0.064)\end{array}$ \\
\hline Share of unemployed & & $\begin{array}{c}1.02^{* * *} \\
(0.32)\end{array}$ & $\begin{array}{c}0.96^{* * *} \\
(0.33)\end{array}$ & & $\begin{array}{c}0.37 \\
(0.47)\end{array}$ & $\begin{array}{l}0.43 \\
(0.45)\end{array}$ \\
\hline Change in 2016 unemployment share & & $\begin{array}{l}1.96^{*} \\
(1.05)\end{array}$ & $\begin{array}{l}2.06^{*} \\
(1.06)\end{array}$ & & $\begin{array}{c}-4.04^{* * *} \\
(1.34)\end{array}$ & $\begin{array}{l}-3.98^{* * *} \\
(1.33)\end{array}$ \\
\hline Population density & & $\begin{array}{l}-0.027 \\
(0.023)\end{array}$ & $\begin{array}{l}-0.027 \\
(0.022)\end{array}$ & & $\begin{array}{l}-0.015 \\
(0.022)\end{array}$ & $\begin{array}{l}-0.015 \\
(0.022)\end{array}$ \\
\hline Population size (log) & & $\begin{array}{l}-0.51 \\
(0.38)\end{array}$ & $\begin{array}{l}-0.48 \\
(0.38)\end{array}$ & & $\begin{array}{l}-0.32 \\
(0.43)\end{array}$ & $\begin{array}{l}-0.33 \\
(0.43)\end{array}$ \\
\hline Share of employed in high skilled labor & & $\begin{array}{c}-0.53^{* * *} \\
(0.20)\end{array}$ & $\begin{array}{c}-0.46^{* *} \\
(0.19)\end{array}$ & & $\begin{array}{l}-0.32 \\
(0.21)\end{array}$ & $\begin{array}{l}-0.34^{*} \\
(0.20)\end{array}$ \\
\hline Share of employed in low skilled labor & & $\begin{array}{c}1.06^{* * *} \\
(0.15)\end{array}$ & $\begin{array}{c}1.02^{* * *} \\
(0.15)\end{array}$ & & $\begin{array}{c}1.02^{* * *} \\
(0.15)\end{array}$ & $\begin{array}{l}1.02^{* * *} \\
(0.15)\end{array}$ \\
\hline Share of migrants from outside UK & & $\begin{array}{l}-0.75 \\
(0.66)\end{array}$ & $\begin{array}{l}-0.80 \\
(0.64)\end{array}$ & & $\begin{array}{l}-0.84 \\
(0.62)\end{array}$ & $\begin{array}{l}-0.82 \\
(0.63)\end{array}$ \\
\hline Share of ethnic group white & & $\begin{array}{c}-0.066^{* *} \\
(0.033)\end{array}$ & $\begin{array}{c}-0.079^{* *} \\
(0.033)\end{array}$ & & $\begin{array}{c}-0.11^{* * *} \\
(0.033)\end{array}$ & $\begin{array}{l}-0.11^{* * *} \\
(0.032)\end{array}$ \\
\hline Ukip share in EE & & $\begin{array}{l}0.91^{* * *} \\
(0.039)\end{array}$ & & & $\begin{array}{l}1.02^{* * *} \\
(0.045)\end{array}$ & \\
\hline Constant & $\begin{array}{c}34.8^{* * *} \\
(2.29)\end{array}$ & $\begin{array}{l}48.5^{* * *} \\
(6.84)\end{array}$ & $\begin{array}{l}47.1^{* * *} \\
(6.83)\end{array}$ & $\begin{array}{c}29.2^{* * *} \\
(2.93)\end{array}$ & $\begin{array}{c}37.6^{* * *} \\
(7.51)\end{array}$ & $\begin{array}{l}38.2^{* * *} \\
(7.40)\end{array}$ \\
\hline $\mathrm{N}$ & 381 & 381 & 381 & 275 & 275 & 275 \\
\hline
\end{tabular}

OLS regression with robust standard errors in parentheses, i.e. difference in 2016 referendum turnout and 2014 European election turnout is main independent variable. Otherwise see notes to Table 2.

$* *(*, * *)$ indicates $\mathrm{p}<0.05(0.1,0.01)$ 
Table A.7: Reduced form estimates of the direct effect of election day rainfall on Leave support

\begin{tabular}{|c|c|c|c|c|c|c|}
\hline & \multicolumn{3}{|c|}{ Full sample } & \multicolumn{3}{|c|}{ Adjacent sample } \\
\hline & (1) & $(2)$ & (3) & $(4)$ & $(5)$ & $(6)$ \\
\hline & $\begin{array}{l}\text { Diff. Leave - } \\
\text { Ukip share }\end{array}$ & $\begin{array}{c}\text { Leave in } \\
\%\end{array}$ & $\begin{array}{l}\text { Diff. Leave - } \\
\text { Ukip share }\end{array}$ & $\begin{array}{l}\text { Diff. Leave - } \\
\text { Ukip share }\end{array}$ & $\begin{array}{c}\text { Leave in } \\
\%\end{array}$ & $\begin{array}{l}\text { Diff. Leave - } \\
\text { Ukip share }\end{array}$ \\
\hline Average election day rainfall $(\mathrm{mm})$ & $\begin{array}{c}-0.29^{* * *} \\
(0.072)\end{array}$ & $\begin{array}{c}-0.089^{* * *} \\
(0.031)\end{array}$ & $\begin{array}{c}-0.12^{* * *} \\
(0.029)\end{array}$ & $\begin{array}{c}-0.16^{* * *} \\
(0.062)\end{array}$ & $\begin{array}{c}-0.10^{* * *} \\
(0.030)\end{array}$ & $\begin{array}{l}-0.087^{* * *} \\
(0.026)\end{array}$ \\
\hline Wales & & $\begin{array}{l}-1.33^{*} \\
(0.77)\end{array}$ & $\begin{array}{l}-0.85 \\
(0.77)\end{array}$ & & & \\
\hline Scotland & & $\begin{array}{c}0.32 \\
(1.33)\end{array}$ & $\begin{array}{l}2.22^{* *} \\
(0.96)\end{array}$ & & & \\
\hline London & & $\begin{array}{c}2.71^{* * * *} \\
(1.00)\end{array}$ & $\begin{array}{c}2.94^{* * *} \\
(0.97)\end{array}$ & & $\begin{array}{l}2.10^{* *} \\
(0.94)\end{array}$ & $\begin{array}{l}2.01^{* *} \\
(0.97)\end{array}$ \\
\hline Northern Ireland & & $\begin{array}{c}14.3^{* * *} \\
(1.71)\end{array}$ & $\begin{array}{c}16.8^{* * *} \\
(1.30)\end{array}$ & & & \\
\hline Share of population aged $20-30$ & & $\begin{array}{c}-0.65^{* * *} \\
(0.20)\end{array}$ & $\begin{array}{c}-0.59^{* * *} \\
(0.19)\end{array}$ & & $\begin{array}{c}-0.45^{* *} \\
(0.19)\end{array}$ & $\begin{array}{l}-0.50^{* *} \\
(0.20)\end{array}$ \\
\hline Share of population aged $60+$ & & $\begin{array}{l}-0.15^{* *} \\
(0.066)\end{array}$ & $\begin{array}{l}-0.15^{* *} \\
(0.066)\end{array}$ & & $\begin{array}{l}-0.14^{* *} \\
(0.061)\end{array}$ & $\begin{array}{c}-0.14^{* *} \\
(0.062)\end{array}$ \\
\hline Share of unemployed & & $\begin{array}{c}1.08^{* * *} \\
(0.32)\end{array}$ & $\begin{array}{c}1.05^{* * *} \\
(0.32)\end{array}$ & & $\begin{array}{c}0.31 \\
(0.46)\end{array}$ & $\begin{array}{l}0.43 \\
(0.44)\end{array}$ \\
\hline Change in 2016 unemployment share & & $\begin{array}{c}1.61 \\
(1.04)\end{array}$ & $\begin{array}{l}1.60 \\
(1.05)\end{array}$ & & $\begin{array}{c}-4.33^{* * *} \\
(1.33)\end{array}$ & $\begin{array}{l}-4.16^{* * *} \\
(1.31)\end{array}$ \\
\hline Population density & & $\begin{array}{l}-0.024 \\
(0.023)\end{array}$ & $\begin{array}{c}-0.022 \\
(0.022)\end{array}$ & & $\begin{array}{l}-0.013 \\
(0.021)\end{array}$ & $\begin{array}{l}-0.015 \\
(0.022)\end{array}$ \\
\hline Population size $(\log )$ & & $\begin{array}{l}-0.58 \\
(0.39)\end{array}$ & $\begin{array}{l}-0.59 \\
(0.39)\end{array}$ & & $\begin{array}{l}-0.42 \\
(0.43)\end{array}$ & $\begin{array}{l}-0.45 \\
(0.43)\end{array}$ \\
\hline Share of employed in high skilled labor & & $\begin{array}{c}-0.63^{* * *} \\
(0.20)\end{array}$ & $\begin{array}{c}-0.60^{* * *} \\
(0.19)\end{array}$ & & $\begin{array}{l}-0.36^{*} \\
(0.20)\end{array}$ & $\begin{array}{l}-0.41^{* *} \\
(0.20)\end{array}$ \\
\hline Share of employed in low skilled labor & & $\begin{array}{c}0.99^{* * *} \\
(0.15)\end{array}$ & $\begin{array}{c}0.93^{* * *} \\
(0.15)\end{array}$ & & $\begin{array}{c}0.95^{* * *} \\
(0.15)\end{array}$ & $\begin{array}{l}0.97^{* * *} \\
(0.15)\end{array}$ \\
\hline Share of migrants from outside UK & & $\begin{array}{l}-0.61 \\
(0.68)\end{array}$ & $\begin{array}{l}-0.60 \\
(0.65)\end{array}$ & & $\begin{array}{l}-0.70 \\
(0.61)\end{array}$ & $\begin{array}{l}-0.70 \\
(0.63)\end{array}$ \\
\hline Share of ethnic group white & & $\begin{array}{c}-0.088^{* * *} \\
(0.032)\end{array}$ & $\begin{array}{c}-0.11^{* * *} \\
(0.032)\end{array}$ & & $\begin{array}{c}-0.12^{* * *} \\
(0.034)\end{array}$ & $\begin{array}{l}-0.11^{* * *} \\
(0.032)\end{array}$ \\
\hline Ukip share in EE & & $\begin{array}{l}0.92^{* * *} \\
(0.040)\end{array}$ & & & $\begin{array}{l}1.05^{* * *} \\
(0.045)\end{array}$ & \\
\hline Constant & $\begin{array}{c}24.9^{* * * *} \\
(0.33)\end{array}$ & $\begin{array}{c}48.3^{* * *} \\
(6.75)\end{array}$ & $\begin{array}{c}47.1^{* * * *} \\
(6.75)\end{array}$ & $\begin{array}{c}23.4^{* * * *} \\
(0.38)\end{array}$ & $\begin{array}{c}40.0^{* * * *} \\
(7.20)\end{array}$ & $\begin{array}{l}41.3^{* * *} \\
(7.02)\end{array}$ \\
\hline $\mathrm{N}$ & 381 & 381 & 381 & 275 & 275 & 275 \\
\hline
\end{tabular}

Table reports estimates of rainfall (in $\mathrm{mm}$ ) on Leave support (for specification dependent variable see model header). Robust standard errors in parantheses. Otherwise see notes to Table 1.

$* *(*, * * *)$ indicates $\mathrm{p}<0.05(0.1,0.01)$ 


\section{A.4 Preference Gap Calculation}

The substantive relevance of the estimates can be assessed using the framework and terminology proposed by Fowler (2015). Taking our results literally, it is possible to disentangle vote preferences for regular and among occasional voters. With rainfall, only regular voters turn out to vote - they vote irrespective of weather conditions. We call the share of regular voters $S_{R}$. With good weather, also occasional voters are drawn to the polls - they only vote in good weather. We call the share of occasional voters $S_{O}$. They are identified by the effect of rainfall on electoral participation. Ultimately, we are interested in the preference gap $\left(P_{R}-P_{O}\right)$ between these occasional voters $\left(P_{O}\right)$ compared to the regular $\left(P_{R}\right)$ voters. As shown by Fowler (2015), this can be derived from the (reduced form) treatment effect on vote shares (which we call $\Delta P$ ) and the quantities above.

To estimate $\Delta P$ and $P_{R}$ we draw on model 5 of Table 2 , i.e. on the effect of rainfall on the Leave vote in the adjacent sample. To estimate $S_{O}$ and $S_{R}$ we draw on the corresponding specification of the first stage as presented in model 6 of Table A.4. We additionally compute 95\% confidence intervals from bootstrapped standard errors.

Model 6 of Table A.4 allows us to predict average turnout in rainfall areas to 75.05 [74.37; 75.75]. This is $S_{R}$, the share of regular voters. As well, the coefficient of the turnout increase of 0.14 allows us, taken together with average rainfall of $5.99 \mathrm{~mm}$, to estimate the share of occasional voters to $0.81[.45 ; 1.14]$.

The same exercise is applied to the reduced form equation to predict average leave support in rainfall areas to $53.32[51.73 ; 54.84]$ percent, i.e. $P_{R}$, and the effect of rainfall $(\Delta V)$ to $0.57[0.29 ; 1.01]$.

The preference gap is then given by $P_{M}-P_{R}=\Delta P\left(1+S_{R} / S_{M}\right)$ (see Fowler, 2015). We estimate the preference gap to 56.17 [24.68, 135.19] percentage points and the share of Leave voters among the occasional voter population to 109.49 [78.23, 188.39].

Note that the point estimate and upper bound of the confidence interval for the share of Leave support in the occasinal voter population exceed $100 \%$. This hints to the possibility of spill-over effects and/or direct effects of rainfall on Leave support.

Importantly, though, the large preference gap and the high amount of estimated Leave support among the occasional voter population imply that Brexit support among the occasional voter population is very heavily leaning towards Leave, the lower bound of the confidence interval beginning at 78.23 percent.

Note that these calculations invoke very strong assumptions: We should therefore not directly interpret the absolute size of the preference-gap; nonetheless, it gives numeric support that an average (weather induced) occasional voter and an average regular voter differ very much with respect to their preferences on EU membership in the case at hand and that occasional voter population consisted overproportionally of Leave supporters.

Note as well that this does not imply that only mobilization mattered and persuasion was irrelevant. The point estimates in model 5 of Table 2 suggest that a one percentage

\footnotetext{
${ }^{19}$ These estimates apply only to an average English districts/boroughs in the sample at hand. Additional assumptions are invoked on the functional form of the predictions of turnout and vote shares, concerning the instrument, and (not) weighting the observations by varying population size; it is as well left aside that the referendum likely brought other occasional voters to the polls, as predicted turnout under rainfall is still higher than average general election turnout. Additionally, the uncertainty involved is large.
} 
point increase in turnout led to around a 0.74 percentage point increase in the share of the Leave campaign. For the adjacent sample, turnout increased overall by around 38.5 percentage points from $36.6 \%$ to $75.1 \%$; EU opposition increased by 22.7 percentage points from a Ukip share of $31.4 \%$ to a Leave share of $54.1 \%$. Assume for a moment that persuasion did not occur, i.e. that all Ukip supporters remained in the Leave camp and vice versa. If we then assume a constant effects framework, the average increase in turnout of around 38.1 percentage points should have led to an increase in the Leave vote slightly below 30 percentage points (e.g. $28.2[7.3,49.7]$ percentage points with an ATE of 0.74 as of model $5)$. As we do not observe this increase, persuasion is likely an important part of the story as well. (Note the wide confidence intervals. Calculations based on these models therefore have to be treated with caution.)

\section{A.5 Robustness tests}

The following appendix tables provide results of the robustness tests referenced in the robustness section of the main text. 


\section{Table A.8: Instrument relevance and IV regression with 2016 referendum turnout}

\begin{tabular}{|c|c|c|c|c|}
\hline \multirow[b]{2}{*}{ Dependent variable } & \multicolumn{2}{|c|}{ Instrument relevance } & \multicolumn{2}{|c|}{ IV regression } \\
\hline & $\begin{array}{c}\text { Full sample } \\
(1) \\
\text { Referendum turnout } \\
\text { in } \%\end{array}$ & $\begin{array}{c}\text { Adjacent sample } \\
(2) \\
\text { Referendum turnout } \\
\text { in } \%\end{array}$ & \begin{tabular}{|c|} 
Full sample \\
$(3)$ \\
Diff. 2016 Leave - \\
2014 Ukip share \\
\end{tabular} & $\begin{array}{c}\text { Adjacent sample } \\
(4) \\
\text { Diff. 2016 Leave - } \\
\text { 2014 Ukip share } \\
\end{array}$ \\
\hline Average election day rainfall $(\mathrm{mm})$ & $\begin{array}{c}-0.034^{*} \\
(0.019)\end{array}$ & $\begin{array}{c}-0.046^{* *} \\
(0.018)\end{array}$ & & \\
\hline Referendum turnout in \% & & & $\begin{array}{c}6.29 \\
(6.85)\end{array}$ & $\begin{array}{l}1.44^{*} \\
(0.78)\end{array}$ \\
\hline Share of population aged $20-30$ & $\begin{array}{l}-0.20^{*} \\
(0.12)\end{array}$ & $\begin{array}{c}-0.28^{* * *} \\
(0.10)\end{array}$ & $\begin{array}{c}0.87 \\
(1.77)\end{array}$ & $\begin{array}{l}-0.12 \\
(0.35)\end{array}$ \\
\hline Share of population aged $60+$ & $\begin{array}{l}-0.055 \\
(0.037)\end{array}$ & $\begin{array}{c}-0.11^{* * *} \\
(0.035)\end{array}$ & $\begin{array}{c}0.17 \\
(0.42)\end{array}$ & $\begin{array}{l}0.060 \\
(0.13)\end{array}$ \\
\hline Share of unemployed & $\begin{array}{c}-2.51^{* * *} \\
(0.21)\end{array}$ & $\begin{array}{c}-1.78^{* * *} \\
(0.23)\end{array}$ & $\begin{array}{c}16.8 \\
(17.3)\end{array}$ & $\begin{array}{l}2.84^{*} \\
(1.51)\end{array}$ \\
\hline Change in 2016 unemployment share & $\begin{array}{c}0.81 \\
(0.58)\end{array}$ & $\begin{array}{l}2.03^{* * *} \\
(0.73)\end{array}$ & $\begin{array}{l}-3.53 \\
(7.28)\end{array}$ & $\begin{array}{c}-6.58^{* * *} \\
(2.45)\end{array}$ \\
\hline Population density & $\begin{array}{l}-0.023 \\
(0.014)\end{array}$ & $\begin{array}{c}-0.027^{* *} \\
(0.012)\end{array}$ & $\begin{array}{c}0.13 \\
(0.20)\end{array}$ & $\begin{array}{c}0.021 \\
(0.038)\end{array}$ \\
\hline Population size $(\log )$ & $\begin{array}{l}-0.069 \\
(0.21)\end{array}$ & $\begin{array}{c}-0.44^{* *} \\
(0.18)\end{array}$ & $\begin{array}{c}-0.16 \\
(1.48)\end{array}$ & $\begin{array}{c}0.18 \\
(0.60)\end{array}$ \\
\hline Share of employed in high skilled labor & $\begin{array}{l}0.39^{* * *} \\
(0.093)\end{array}$ & $\begin{array}{c}0.23^{* *} \\
(0.090)\end{array}$ & $\begin{array}{l}-2.91 \\
(2.67)\end{array}$ & $\begin{array}{c}-0.82^{* *} \\
(0.34)\end{array}$ \\
\hline Share of employed in low skilled labor & $\begin{array}{l}-0.14^{*} \\
(0.080)\end{array}$ & $\begin{array}{l}-0.18^{* *} \\
(0.078)\end{array}$ & $\begin{array}{l}1.63^{*} \\
(0.93)\end{array}$ & $\begin{array}{c}1.14^{* * *} \\
(0.25)\end{array}$ \\
\hline Share of migrants from outside UK & $\begin{array}{l}-0.28 \\
(0.40)\end{array}$ & $\begin{array}{l}-0.49^{*} \\
(0.29)\end{array}$ & $\begin{array}{c}1.21 \\
(3.64)\end{array}$ & $\begin{array}{l}0.025 \\
(0.97)\end{array}$ \\
\hline Share of ethnic group & $\begin{array}{c}0.090^{* * *} \\
(0.023)\end{array}$ & $\begin{array}{l}0.12^{* * *} \\
(0.023)\end{array}$ & $\begin{array}{l}-0.73 \\
(0.68)\end{array}$ & $\begin{array}{c}-0.29^{* * *} \\
(0.099)\end{array}$ \\
\hline Wales & $\begin{array}{l}0.086 \\
(0.43)\end{array}$ & & $\begin{array}{c}0.36 \\
(3.08)\end{array}$ & \\
\hline Scotland & $\begin{array}{c}-3.17^{* * *} \\
(0.87)\end{array}$ & & $\begin{array}{c}28.9 \\
(28.8)\end{array}$ & \\
\hline London & $\begin{array}{c}0.16 \\
(0.68)\end{array}$ & $\begin{array}{r}-0.092 \\
(0.68)\end{array}$ & $\begin{array}{c}2.67 \\
(4.69)\end{array}$ & $\begin{array}{l}2.84^{*} \\
(1.62)\end{array}$ \\
\hline Norther Ireland & $\begin{array}{c}-9.21^{* * *} \\
(1.15)\end{array}$ & & $\begin{array}{l}82.8 \\
(70.5)\end{array}$ & \\
\hline Turnout for $2014 \mathrm{EE}$ & $\begin{array}{l}0.22^{* * *} \\
(0.039)\end{array}$ & $\begin{array}{l}0.29^{* * *} \\
(0.040)\end{array}$ & $\begin{array}{l}-1.35 \\
(1.40)\end{array}$ & $\begin{array}{c}-0.61^{* *} \\
(0.24)\end{array}$ \\
\hline UKIP share in EE & $\begin{array}{l}0.045^{*} \\
(0.023)\end{array}$ & $\begin{array}{l}-0.023 \\
(0.027)\end{array}$ & & \\
\hline Constant & $\begin{array}{c}63.3^{* * *} \\
(5.11)\end{array}$ & $\begin{array}{c}69.2^{* * *} \\
(5.26) \\
\end{array}$ & $\begin{array}{l}-357.1 \\
(443.0) \\
\end{array}$ & $\begin{array}{l}-47.6 \\
(53.6) \\
\end{array}$ \\
\hline $\mathrm{N}$ & 381 & 275 & 381 & 275 \\
\hline
\end{tabular}


Table A.9: Instrument relevance with binary rainfall indicator (above median rainfall): Effect of rainfall on turnout increase

\begin{tabular}{|c|c|c|c|c|}
\hline & \multicolumn{4}{|c|}{ Dep. var.: 2016 Referendum - 2014 EE TO } \\
\hline & \multicolumn{2}{|c|}{ Full sample } & \multicolumn{2}{|c|}{ Adjacent sample } \\
\hline & $(1)$ & $(2)$ & $(3)$ & $(4)$ \\
\hline Above median rainfall & $\begin{array}{c}-2.09^{* * *} \\
(0.73)\end{array}$ & $\begin{array}{c}-0.90^{* *} \\
(0.35)\end{array}$ & $\begin{array}{c}-3.43^{* * *} \\
(0.73)\end{array}$ & $\begin{array}{c}-1.19^{* * *} \\
(0.34)\end{array}$ \\
\hline Wales & & $\begin{array}{l}1.17^{*} \\
(0.65)\end{array}$ & & \\
\hline Scotland & & $\begin{array}{c}-4.05^{* * *} \\
(1.10)\end{array}$ & & \\
\hline London & & $\begin{array}{c}-2.52^{* *} \\
(0.98)\end{array}$ & & $\begin{array}{c}-2.98^{* * *} \\
(0.95)\end{array}$ \\
\hline Northern Ireland & & $\begin{array}{c}-25.8^{* * *} \\
(1.23)\end{array}$ & & \\
\hline Share of population aged $20-30$ & & $\begin{array}{c}-0.33^{* *} \\
(0.13)\end{array}$ & & $\begin{array}{c}-0.33^{* *} \\
(0.13)\end{array}$ \\
\hline Share of population aged $60+$ & & $\begin{array}{c}-0.24^{* * *} \\
(0.055)\end{array}$ & & $\begin{array}{c}-0.25^{* * *} \\
(0.054)\end{array}$ \\
\hline Share of unemployed & & $\begin{array}{c}-1.43^{* * *} \\
(0.30)\end{array}$ & & $\begin{array}{c}-1.00^{* * *} \\
(0.34)\end{array}$ \\
\hline Change in 2016 unemployment share & & $\begin{array}{c}0.76 \\
(1.06)\end{array}$ & & $\begin{array}{c}0.63 \\
(1.15)\end{array}$ \\
\hline Population density & & $\begin{array}{l}-0.019 \\
(0.015)\end{array}$ & & $\begin{array}{c}-0.017 \\
(0.015)\end{array}$ \\
\hline Population size (log) & & $\begin{array}{r}-0.040 \\
(0.35)\end{array}$ & & $\begin{array}{l}-0.47 \\
(0.29)\end{array}$ \\
\hline Share of employed in high skilled labor & & $\begin{array}{c}0.58^{* * *} \\
(0.13)\end{array}$ & & $\begin{array}{c}0.50^{* * *} \\
(0.12)\end{array}$ \\
\hline Share of employed in low skilled labor & & $\begin{array}{c}0.30^{* * *} \\
(0.12)\end{array}$ & & $\begin{array}{c}0.18 \\
(0.11)\end{array}$ \\
\hline Share of migrants from outside UK & & $\begin{array}{l}-0.17 \\
(0.42)\end{array}$ & & $\begin{array}{l}-0.49 \\
(0.39)\end{array}$ \\
\hline Share of ethnic group & & $\begin{array}{l}0.19^{* * *} \\
(0.031)\end{array}$ & & $\begin{array}{l}0.17^{* * *} \\
(0.030)\end{array}$ \\
\hline Constant & $\begin{array}{c}38.4^{* * *} \\
(0.29)\end{array}$ & $\begin{array}{c}25.1^{* * *} \\
(7.42)\end{array}$ & $\begin{array}{c}39.8^{* * *} \\
(0.29)\end{array}$ & $\begin{array}{c}34.8^{* * *} \\
(6.44)\end{array}$ \\
\hline $\mathrm{N}$ & 381 & 381 & 275 & 275 \\
\hline r2_a & 0.025 & 0.69 & 0.093 & 0.77 \\
\hline $\mathrm{F}$ & 8.13 & 45.5 & 21.9 & 53.0 \\
\hline
\end{tabular}


Table A.10: Instrumental variable regression of difference in EE to Referendum turnout on Leave share/increase in Leave vote with binary instrument (above median rainfall)

\begin{tabular}{|c|c|c|c|c|c|c|}
\hline & \multicolumn{3}{|c|}{ Full sample } & \multicolumn{3}{|c|}{ Adjacent sample } \\
\hline & (1) & $(2)$ & (3) & $(4)$ & $(5)$ & $(6)$ \\
\hline & $\begin{array}{c}\text { Diff. Leave - } \\
\text { Ukip share }\end{array}$ & $\begin{array}{c}\text { Leave in } \\
\%\end{array}$ & $\begin{array}{l}\text { Diff. Leave - } \\
\text { Ukip share }\end{array}$ & $\begin{array}{l}\text { Diff. Leave - } \\
\text { Ukip share }\end{array}$ & $\begin{array}{c}\text { Leave in } \\
\%\end{array}$ & $\begin{array}{c}\text { Diff. Leave - } \\
\text { Ukip share }\end{array}$ \\
\hline 2016 Referendum TO - 2014 EE TO & $\begin{array}{l}1.78^{* *} \\
(0.78)\end{array}$ & $\begin{array}{l}0.71^{* *} \\
(0.36)\end{array}$ & $\begin{array}{c}1.41^{*} \\
(0.73)\end{array}$ & $\begin{array}{l}0.64^{* *} \\
(0.26)\end{array}$ & $\begin{array}{l}0.71^{* *} \\
(0.31)\end{array}$ & $\begin{array}{l}0.81^{* *} \\
(0.38)\end{array}$ \\
\hline Wales & & $\begin{array}{c}-2.90^{* *} \\
(1.26)\end{array}$ & $\begin{array}{l}-2.33 \\
(1.71)\end{array}$ & & & \\
\hline Scotland & & $\begin{array}{l}0.020 \\
(1.78)\end{array}$ & $\begin{array}{l}8.03^{* *} \\
(3.48)\end{array}$ & & & \\
\hline London & & $\begin{array}{c}4.04^{* * *} \\
(1.45)\end{array}$ & $\begin{array}{l}6.36^{* *} \\
(2.51)\end{array}$ & & $\begin{array}{c}3.91^{* * *} \\
(1.51)\end{array}$ & $\begin{array}{l}4.27^{* *} \\
(1.75)\end{array}$ \\
\hline Northern Ireland & & $\begin{array}{c}28.3^{* * *} \\
(8.13)\end{array}$ & $\begin{array}{c}52.9^{* * *} \\
(19.1)\end{array}$ & & & \\
\hline Share of population aged $20-30$ & & $\begin{array}{c}-0.54^{* *} \\
(0.26)\end{array}$ & $\begin{array}{l}-0.17 \\
(0.37)\end{array}$ & & $\begin{array}{l}-0.35 \\
(0.25)\end{array}$ & $\begin{array}{l}-0.27 \\
(0.27)\end{array}$ \\
\hline Share of population aged $60+$ & & $\begin{array}{l}0.022 \\
(0.12)\end{array}$ & $\begin{array}{c}0.17 \\
(0.21)\end{array}$ & & $\begin{array}{l}0.031 \\
(0.11)\end{array}$ & $\begin{array}{l}0.052 \\
(0.13)\end{array}$ \\
\hline Share of unemployed & & $\begin{array}{c}2.15^{* * *} \\
(0.67)\end{array}$ & $\begin{array}{c}3.11^{* * *} \\
(1.19)\end{array}$ & & $\begin{array}{l}1.27^{* *} \\
(0.63)\end{array}$ & $\begin{array}{l}1.25^{*} \\
(0.65)\end{array}$ \\
\hline Change in 2016 unemployment share & & $\begin{array}{c}1.12 \\
(1.32)\end{array}$ & $\begin{array}{c}0.65 \\
(2.00)\end{array}$ & & $\begin{array}{c}-4.35^{* * *} \\
(1.53)\end{array}$ & $\begin{array}{l}-4.55^{* * *} \\
(1.61)\end{array}$ \\
\hline Population density & & $\begin{array}{c}-0.011 \\
(0.030)\end{array}$ & $\begin{array}{l}0.0070 \\
(0.039)\end{array}$ & & $\begin{array}{r}-0.0015 \\
(0.027)\end{array}$ & $\begin{array}{l}0.0016 \\
(0.028)\end{array}$ \\
\hline Population size (log) & & $\begin{array}{l}-0.56 \\
(0.47)\end{array}$ & $\begin{array}{l}-0.53 \\
(0.64)\end{array}$ & & $\begin{array}{l}-0.14 \\
(0.50)\end{array}$ & $\begin{array}{l}-0.070 \\
(0.51)\end{array}$ \\
\hline Share of employed in high skilled labor & & $\begin{array}{c}-1.09^{* * *} \\
(0.33)\end{array}$ & $\begin{array}{c}-1.40^{* * *} \\
(0.52)\end{array}$ & & $\begin{array}{c}-0.79^{* * *} \\
(0.28)\end{array}$ & $\begin{array}{l}-0.79^{* * *} \\
(0.29)\end{array}$ \\
\hline Share of employed in low skilled labor & & $\begin{array}{c}0.85^{* * *} \\
(0.21)\end{array}$ & $\begin{array}{c}0.50 \\
(0.36)\end{array}$ & & $\begin{array}{c}0.86^{* * *} \\
(0.19)\end{array}$ & $\begin{array}{l}0.83^{* * *} \\
(0.20)\end{array}$ \\
\hline Share of migrants from outside UK & & $\begin{array}{l}-0.46 \\
(0.83)\end{array}$ & $\begin{array}{l}-0.30 \\
(0.99)\end{array}$ & & $\begin{array}{l}-0.30 \\
(0.71)\end{array}$ & $\begin{array}{l}-0.26 \\
(0.72)\end{array}$ \\
\hline Share of ethnic group & & $\begin{array}{c}-0.20^{* * *} \\
(0.073)\end{array}$ & $\begin{array}{c}-0.38^{* *} \\
(0.16)\end{array}$ & & $\begin{array}{c}-0.22^{* * *} \\
(0.063)\end{array}$ & $\begin{array}{l}-0.25^{* * *} \\
(0.077)\end{array}$ \\
\hline Ukip share in EE & & $\begin{array}{l}0.79^{* * *} \\
(0.065)\end{array}$ & & & $\begin{array}{l}0.95^{* * *} \\
(0.057)\end{array}$ & \\
\hline Constant & $\begin{array}{l}-43.5 \\
(29.8)\end{array}$ & $\begin{array}{c}33.6^{* * *} \\
(11.4)\end{array}$ & $\begin{array}{l}12.9 \\
(20.5)\end{array}$ & $\begin{array}{l}-1.92 \\
(10.2)\end{array}$ & $\begin{array}{c}19.1 \\
(13.5)\end{array}$ & $\begin{array}{l}14.3 \\
(15.8)\end{array}$ \\
\hline $\mathrm{N}$ & 381 & 381 & 381 & 275 & 275 & 275 \\
\hline
\end{tabular}


Table A.11: Instrument relevance and IV regression with adjacent sample expanded to include Scotland and Northern Ireland

\begin{tabular}{|c|c|c|c|c|c|}
\hline \multirow{3}{*}{$\begin{array}{l}\text { Average election day rainfall (mm) } \\
\end{array}$} & \multicolumn{2}{|c|}{ Instrument relevance } & \multicolumn{3}{|c|}{ IV regressions } \\
\hline & $\begin{array}{l}(1) \\
2016 \text { Referendum TO - } \\
2014 \text { EE TO }\end{array}$ & $\begin{array}{l}\text { (2) } \\
2016 \text { Referendum TO - } \\
2014 \text { EE TO }\end{array}$ & $\begin{array}{c}(3) \\
\text { Diff in } 2016 \text { Leave - } \\
2014 \text { Ukip share }\end{array}$ & $\begin{array}{c}(4) \\
\text { Leave in \% }\end{array}$ & $\begin{array}{c}(5) \\
\text { Diff in } 2016 \text { Leave - } \\
2014 \text { Ukip share }\end{array}$ \\
\hline & $\begin{array}{c}-0.14^{* * *} \\
(0.048)\end{array}$ & $\begin{array}{c}-0.096^{* * *} \\
(0.026)\end{array}$ & & & \\
\hline 2016 Referendum TO - 2014 EE TO & & & $\begin{array}{l}1.60^{* *} \\
(0.77)\end{array}$ & $\begin{array}{l}0.56^{* *} \\
(0.25)\end{array}$ & $\begin{array}{l}0.80^{* *} \\
(0.37)\end{array}$ \\
\hline Scotland & & $\begin{array}{c}-4.43^{* * *} \\
(1.20)\end{array}$ & & $\begin{array}{c}3.63 \\
(2.26)\end{array}$ & $\begin{array}{l}7.22^{* * *} \\
(2.15)\end{array}$ \\
\hline London & & $\begin{array}{c}-2.95^{* * *} \\
(1.00)\end{array}$ & & $\begin{array}{c}4.02^{* * *} \\
(1.31)\end{array}$ & $\begin{array}{c}4.94^{* * *} \\
(1.73)\end{array}$ \\
\hline Northern Ireland & & $\begin{array}{l}-25.0^{* * *} \\
(1.46)\end{array}$ & & $\begin{array}{c}27.7^{* * *} \\
(6.29)\end{array}$ & $\begin{array}{l}37.0^{* * *} \\
(9.50)\end{array}$ \\
\hline Share of population aged $20-30$ & & $\begin{array}{c}-0.24^{*} \\
(0.14)\end{array}$ & & $\begin{array}{c}-0.52^{* *} \\
(0.24)\end{array}$ & $\begin{array}{l}-0.39 \\
(0.25)\end{array}$ \\
\hline Share of population aged $60+$ & & $\begin{array}{c}-0.20^{* * *} \\
(0.059)\end{array}$ & & $\begin{array}{l}-0.044 \\
(0.094)\end{array}$ & $\begin{array}{c}-0.0018 \\
(0.11)\end{array}$ \\
\hline Share of unemployed & & $\begin{array}{c}-1.25^{* * *} \\
(0.35)\end{array}$ & & $\begin{array}{l}1.24^{* *} \\
(0.56)\end{array}$ & $\begin{array}{l}1.37^{* *} \\
(0.66)\end{array}$ \\
\hline Change in 2016 unemployment share & & $\begin{array}{c}1.85 \\
(1.19)\end{array}$ & & $\begin{array}{l}-1.31 \\
(1.59)\end{array}$ & $\begin{array}{l}-2.00 \\
(1.79)\end{array}$ \\
\hline Population density & & $\begin{array}{l}-0.024 \\
(0.015)\end{array}$ & & $\begin{array}{l}-0.0014 \\
(0.026)\end{array}$ & $\begin{array}{l}0.0068 \\
(0.029)\end{array}$ \\
\hline Population size (log) & & $\begin{array}{l}-0.19 \\
(0.36)\end{array}$ & & $\begin{array}{l}-0.12 \\
(0.45)\end{array}$ & $\begin{array}{l}-0.089 \\
(0.50)\end{array}$ \\
\hline Share of employed in high skilled labor & & $\begin{array}{c}0.55^{* * *} \\
(0.13)\end{array}$ & & $\begin{array}{c}-0.81^{* * *} \\
(0.27)\end{array}$ & $\begin{array}{c}-0.88^{* * *} \\
(0.32)\end{array}$ \\
\hline Share of employed in low skilled labor & & $\begin{array}{l}0.23^{*} \\
(0.12)\end{array}$ & & $\begin{array}{c}1.00^{* * *} \\
(0.19)\end{array}$ & $\begin{array}{c}0.91^{* * *} \\
(0.22)\end{array}$ \\
\hline Share of migrants from outside UK & & $\begin{array}{l}-0.48 \\
(0.43)\end{array}$ & & $\begin{array}{l}-0.27 \\
(0.72)\end{array}$ & $\begin{array}{l}-0.17 \\
(0.76)\end{array}$ \\
\hline Share of ethnic group & & $\begin{array}{l}0.16^{* * *} \\
(0.032)\end{array}$ & & $\begin{array}{r}-0.17^{* * *} \\
(0.057)\end{array}$ & $\begin{array}{r}-0.23^{* * *} \\
(0.074)\end{array}$ \\
\hline Ukip share in EE & & & & $\begin{array}{l}0.91^{* * *} \\
(0.054)\end{array}$ & \\
\hline Constant & $\begin{array}{c}38.5^{* * *} \\
(0.36)\end{array}$ & $\begin{array}{c}28.9^{* * *} \\
(7.64)\end{array}$ & $\begin{array}{l}-37.7 \\
(29.4)\end{array}$ & $\begin{array}{l}24.4^{* *} \\
(11.0)\end{array}$ & $\begin{array}{c}16.0 \\
(13.8)\end{array}$ \\
\hline $\mathrm{N}$ & 308 & 308 & 308 & 308 & 308 \\
\hline
\end{tabular}

Standard errors in parentheses

${ }^{*} p<0.1,{ }^{* *} p<0.05,{ }^{* * *} p<0.01$

Left panel displays results of a regression (robust standard errors in parantheses) of average rainfall on election day on referendum turnout. Right panel displays results of an IV regression using rainfall as instrument for referendum day turnout. Dependent variables are denoted in model header. Models draw on a restricted sample of observations (all local authorities from regions that experience variation in rainfall).

$* *(*, * * *)$ indicates $\mathrm{p}<0.05(0.1,0.01)$ 


\section{A.6 Survey evidence on Brexit preferences of regular and occa- sional voters}

This Appendix Section provides supporting material for the survey evidence presented in the main paper. Appendix Table A.12 presents logistic regressions that confirm the relationsships depicted in Table 3 under inclusion of control variables. Note that the interpretation of coefficients is not straightforward, as these socio-demographic and political controls are likely also mediating factors for the correlations in Table 3. Appendix Figure A.3 reproduces the average marginal effects Figure 2 without (left panel) and with (right panel) inclusion of control variables and Appendix Table A.13 presents the corresponding coefficient estimates on which these average marginal effects are based.

Figure A.3: Change in predicted probability of turnout between Ukip and non-Ukip supporters in the 12 pre-referendum weeks with and without control variables (comp. Figure 2)
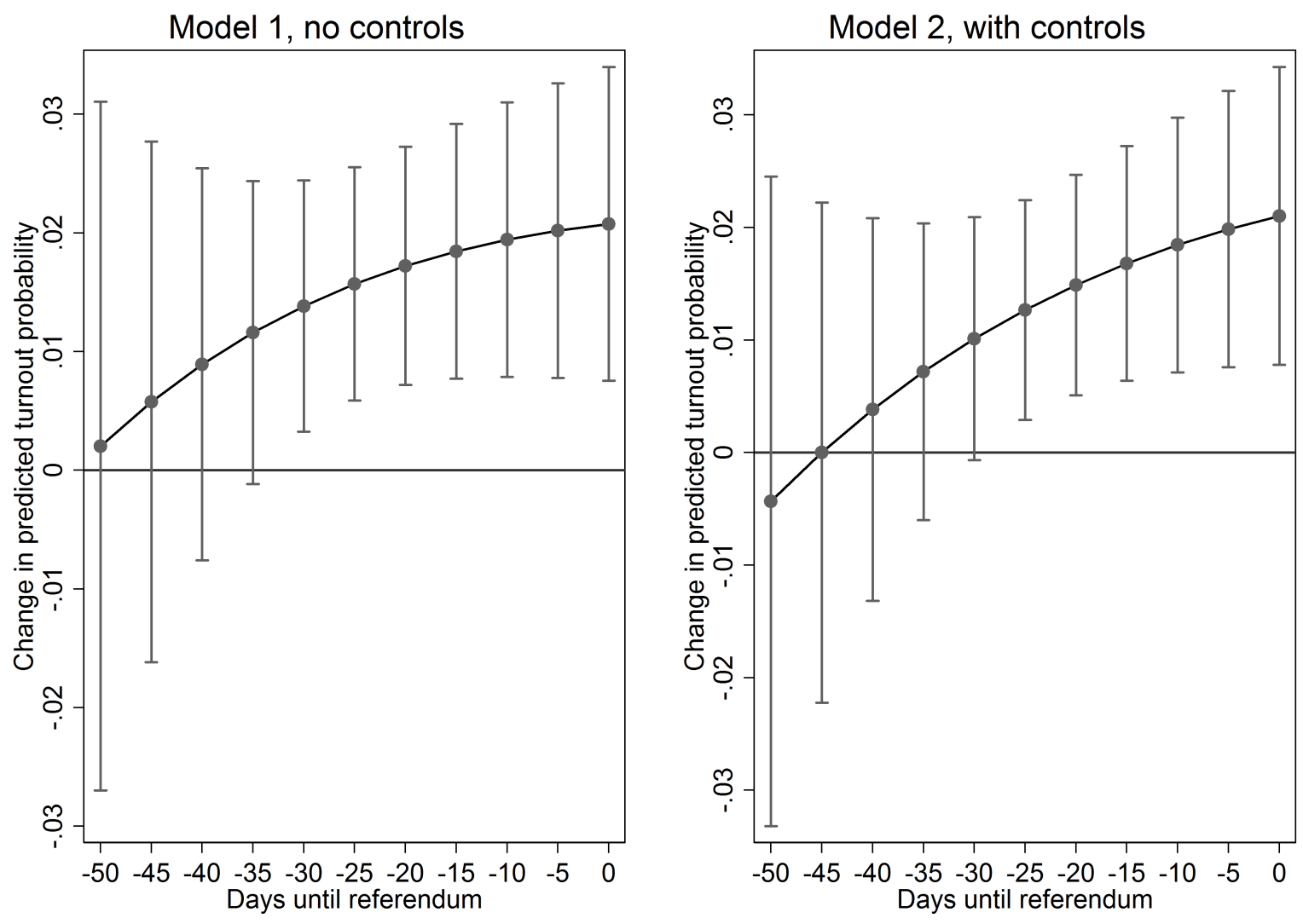

Predictions for Average Marginal Effects from binary logistic regression with dependent variable self-assessed turnout intention ('fairly likely' or 'very likely') and independent variable whether respondent supported UKIP at general election, whether he/she responded 1-48 days before the referendum and interaction term. BES survey weights for representative sample of Great Britain used. 95\% confidence intervals are shown. Weighted $\mathrm{N}=12,636$ (left panel). Right panel (weighted $\mathrm{N}=12,551$ ) includes control variables as in Model 2 of Appendix Table A.13. 
Table A.12: Logistic regression for associations presented in Table 3. Regression on variable indicated in model header. BES survey weights used.

\begin{tabular}{|c|c|c|c|c|c|}
\hline & $\begin{array}{c}(1) \\
\text { Occasional } \\
\text { voter }\end{array}$ & $\begin{array}{c}(2) \\
\text { Referendum interest } \\
\text { very high }\end{array}$ & $\begin{array}{c}(3) \\
\text { Referendum turnout } \\
\text { very likely }\end{array}$ & $\begin{array}{c}(4) \\
\text { Referendum turnout } \\
\text { very likely }\end{array}$ & $\begin{array}{c}(5) \\
\text { Referendum turnout } \\
\text { very likely }\end{array}$ \\
\hline $\begin{array}{l}\text { main } \\
\text { Leave preference }\end{array}$ & $\begin{array}{c}0.071 \\
(0.068)\end{array}$ & $\begin{array}{c}0.34^{* * *} \\
(0.13)\end{array}$ & $\begin{array}{l}0.36^{* *} \\
(0.15)\end{array}$ & & \\
\hline Sov./Imm. most important & & & & $\begin{array}{c}0.52^{* * *} \\
(0.19)\end{array}$ & \\
\hline Econ. most important & & & & & $\begin{array}{c}-0.48^{* *} \\
(0.19)\end{array}$ \\
\hline Age & $\begin{array}{c}-0.023^{* * *} \\
(0.0018)\end{array}$ & $\begin{array}{c}0.0031 \\
(0.0037)\end{array}$ & $\begin{array}{l}0.0095^{* *} \\
(0.0042)\end{array}$ & $\begin{array}{c}0.0044 \\
(0.0054)\end{array}$ & $\begin{array}{c}0.0046 \\
(0.0054)\end{array}$ \\
\hline Female & $\begin{array}{c}0.038 \\
(0.054)\end{array}$ & $\begin{array}{l}0.033 \\
(0.11)\end{array}$ & $\begin{array}{c}0.18 \\
(0.11)\end{array}$ & $\begin{array}{c}-0.0031 \\
(0.16)\end{array}$ & $\begin{array}{l}-0.053 \\
(0.16)\end{array}$ \\
\hline Scotland & $\begin{array}{c}-0.26^{* * *} \\
(0.078)\end{array}$ & $\begin{array}{c}-0.54^{* * *} \\
(0.16)\end{array}$ & $\begin{array}{l}-0.071 \\
(0.18)\end{array}$ & $\begin{array}{l}-0.19 \\
(0.23)\end{array}$ & $\begin{array}{l}-0.20 \\
(0.23)\end{array}$ \\
\hline Wales & $\begin{array}{l}-0.047 \\
(0.098)\end{array}$ & $\begin{array}{c}0.30 \\
(0.19)\end{array}$ & $\begin{array}{l}0.074 \\
(0.23)\end{array}$ & $\begin{array}{l}-0.080 \\
(0.32)\end{array}$ & $\begin{array}{l}-0.057 \\
(0.31)\end{array}$ \\
\hline Political attention (0-10) & $\begin{array}{r}-0.19^{* * *} \\
(0.011)\end{array}$ & $\begin{array}{l}0.49^{* * *} \\
(0.027)\end{array}$ & $\begin{array}{l}0.26^{* * *} \\
(0.023)\end{array}$ & $\begin{array}{l}0.25^{* * *} \\
(0.034)\end{array}$ & $\begin{array}{l}0.26^{* * *} \\
(0.034)\end{array}$ \\
\hline Married & $\begin{array}{c}0.016 \\
(0.059)\end{array}$ & $\begin{array}{l}0.21^{*} \\
(0.11)\end{array}$ & $\begin{array}{c}0.13 \\
(0.13)\end{array}$ & $\begin{array}{l}-0.079 \\
(0.17)\end{array}$ & $\begin{array}{l}-0.11 \\
(0.17)\end{array}$ \\
\hline No dependents in $\mathrm{HH}$ & $\begin{array}{l}-0.043 \\
(0.060)\end{array}$ & $\begin{array}{c}0.35^{* * *} \\
(0.12)\end{array}$ & $\begin{array}{c}0.37^{* * *} \\
(0.13)\end{array}$ & $\begin{array}{c}0.21 \\
(0.17)\end{array}$ & $\begin{array}{c}0.21 \\
(0.17)\end{array}$ \\
\hline Houseowner & $\begin{array}{r}-0.49^{* * *} \\
(0.059)\end{array}$ & $\begin{array}{c}-0.094 \\
(0.11)\end{array}$ & $\begin{array}{l}0.048 \\
(0.13)\end{array}$ & $\begin{array}{c}0.12 \\
(0.17)\end{array}$ & $\begin{array}{c}0.15 \\
(0.17)\end{array}$ \\
\hline Unemployed & $\begin{array}{c}0.15 \\
(0.15)\end{array}$ & $\begin{array}{l}-0.24 \\
(0.27)\end{array}$ & $\begin{array}{l}-0.11 \\
(0.26)\end{array}$ & $\begin{array}{l}0.049 \\
(0.47)\end{array}$ & $\begin{array}{l}0.092 \\
(0.47)\end{array}$ \\
\hline White ethnicity & $\begin{array}{c}-0.37^{* * *} \\
(0.090)\end{array}$ & $\begin{array}{l}-0.22 \\
(0.19)\end{array}$ & $\begin{array}{c}0.80^{* * *} \\
(0.17)\end{array}$ & $\begin{array}{c}0.65^{* * *} \\
(0.24)\end{array}$ & $\begin{array}{c}0.68^{* * *} \\
(0.24)\end{array}$ \\
\hline Migrant & $\begin{array}{c}0.59^{* * *} \\
(0.14)\end{array}$ & $\begin{array}{c}0.35 \\
(0.27)\end{array}$ & $\begin{array}{l}-0.23 \\
(0.25)\end{array}$ & $\begin{array}{l}-0.45 \\
(0.32)\end{array}$ & $\begin{array}{l}-0.45 \\
(0.32)\end{array}$ \\
\hline Working class & $\begin{array}{l}-0.29 \\
(0.21)\end{array}$ & $\begin{array}{c}0.42 \\
(0.46)\end{array}$ & $\begin{array}{l}1.04^{*} \\
(0.53)\end{array}$ & $\begin{array}{l}-0.072 \\
(0.64)\end{array}$ & $\begin{array}{c}-0.033 \\
(0.63)\end{array}$ \\
\hline Middle class & $\begin{array}{c}0.043 \\
(0.053)\end{array}$ & $\begin{array}{c}-0.24^{* *} \\
(0.10)\end{array}$ & $\begin{array}{l}-0.039 \\
(0.11)\end{array}$ & $\begin{array}{l}-0.11 \\
(0.16)\end{array}$ & $\begin{array}{l}-0.11 \\
(0.16)\end{array}$ \\
\hline Like/dislike: Ukip & $\begin{array}{l}0.043^{* * *} \\
(0.0099)\end{array}$ & $\begin{array}{r}-0.0030 \\
(0.020)\end{array}$ & $\begin{array}{l}-0.042^{*} \\
(0.022)\end{array}$ & $\begin{array}{l}-0.021 \\
(0.027)\end{array}$ & $\begin{array}{r}-0.0028 \\
(0.025)\end{array}$ \\
\hline Constant & $\begin{array}{l}1.34^{* * *} \\
(0.15)\end{array}$ & $\begin{array}{c}-3.35^{* * *} \\
(0.33)\end{array}$ & $\begin{array}{c}-2.21^{* * *} \\
(0.30)\end{array}$ & $\begin{array}{c}-1.44^{* * *} \\
(0.42)\end{array}$ & $\begin{array}{c}-1.21^{* * *} \\
(0.44)\end{array}$ \\
\hline $\mathrm{N}$ & 14573 & 2744 & 2413 & 1326 & 1326 \\
\hline
\end{tabular}


Table A.13: Logistic regression on self-assessed turnout propensity by past Ukip vote and time to referendum in British Election Study

\begin{tabular}{|c|c|c|}
\hline \multirow{2}{*}{ Referendum turnout likely or very likely } & \multicolumn{2}{|c|}{$\begin{array}{cc}(1) & (2) \\
\text { Referendum turnout likely or very likely }\end{array}$} \\
\hline & & \\
\hline Ukip vote in 2015 general election=1 & $\begin{array}{l}1.12^{* *} \\
(0.49)\end{array}$ & $\begin{array}{l}1.15^{* *} \\
(0.49)\end{array}$ \\
\hline Days until referendum & $\begin{array}{c}0.0062 \\
(0.0050)\end{array}$ & $\begin{array}{c}0.0029 \\
(0.0055)\end{array}$ \\
\hline Ukip vote in 2015 general election $=1 \times$ Days until referendum & $\begin{array}{c}0.021 \\
(0.015)\end{array}$ & $\begin{array}{c}0.025 \\
(0.016)\end{array}$ \\
\hline Age & & $\begin{array}{l}0.023^{* * *} \\
(0.0051)\end{array}$ \\
\hline Female & & $\begin{array}{l}0.082 \\
(0.13)\end{array}$ \\
\hline Scotland & & $\begin{array}{l}-0.14 \\
(0.17)\end{array}$ \\
\hline Wales & & $\begin{array}{c}0.38 \\
(0.28)\end{array}$ \\
\hline Abstention in 2005,2010 or 2015 general election & & $\begin{array}{c}-0.92^{* * *} \\
(0.13)\end{array}$ \\
\hline Political attention $(0-10)$ & & $\begin{array}{l}0.35^{* * *} \\
(0.027)\end{array}$ \\
\hline Married & & $\begin{array}{c}0.12 \\
(0.15)\end{array}$ \\
\hline No dependents in $\mathrm{HH}$ & & $\begin{array}{c}0.18 \\
(0.14)\end{array}$ \\
\hline Houseowner & & $\begin{array}{c}0.11 \\
(0.15)\end{array}$ \\
\hline Unemployed & & $\begin{array}{l}-0.39 \\
(0.48)\end{array}$ \\
\hline White ethnicity & & $\begin{array}{c}0.69^{* * *} \\
(0.22)\end{array}$ \\
\hline Migrant & & $\begin{array}{l}-0.15 \\
(0.34)\end{array}$ \\
\hline Working class & & $\begin{array}{l}0.073 \\
(0.54)\end{array}$ \\
\hline Middle class & & $\begin{array}{l}-0.13 \\
(0.14)\end{array}$ \\
\hline Constant & $\begin{array}{c}3.44^{* * *} \\
(0.16)\end{array}$ & $\begin{array}{l}-0.27 \\
(0.43)\end{array}$ \\
\hline $\mathrm{N}$ & 12636 & 12551 \\
\hline Pseudo R2 & 0.0038 & 0.15 \\
\hline Log likelihood & -1878.1 & -1514.7 \\
\hline
\end{tabular}




\section{References}

Alabrese E, Fetzer T (2018) Who is NOT voting for Brexit anymore ? CAGE Working Paper (December)

Angrist JD, Pischke JS (2009) Mostly Harmless Econometrics: An Empiricist's Companion. Princeton University Press, Princeton

Becker SO, Fetzer T, Novy D (2017) Who Voted for Brexit? A Comprehensive District-Level Analysis. Economic Policy 32(92):601-650

Birch S (2016) Our New Voters: Brexit, Political Mobilisation and the Emerging Electoral Cleavage. Juncture 23(2):107-110

Clarke HD, Goodwin M, Whiteley P (2017) Why Britain Voted for Brexit: An IndividualLevel Analysis of the 2016 Referendum Vote. Parliamentary Affairs 70(3):439-464

Dorling D, Stuart B, Stubbs J (2016) Don't mention this around the Christmas table: Brexit, inequality and the demographic divide. LSE European Politics and Policy (EUROPP) Blog pp 1-10, URL http://eprints.lse.ac.uk/70004/1/blogs.lse.ac. uk-DontmentionthisaroundtheChristmastableBrexitinequalityandthedemographicdivide . pdf

Eichengreen B, Mari R, Thwaites G (2018) Will Brexit Age Well? URL http://www.nber. org/papers/w25219

Evans G, Menon A (2017) Brexit and British politics. John Wiley \& Sons

Fetzer T (2018) Did Austerity Cause Brexit ? Warwick Economics Research Papers 4283(1170):pp. 1-10

Fowler A (2015) Regular Voters, Marginal Voters and the Electoral Effects of Turnout. Political Science Research and Methods 3(2):205-219

Goodwin MJ, Heath O (2016) The 2016 Referendum, Brexit and the Left Behind: An Aggregate-level Analysis of the Result. The Political Quarterly 87(3):323-332

Johnston R, Jones K, Manley D (2018) Predicting Who Voted for Brexitt Through Ecological Analysis An Example of the Problem of Confounding, and its Resolution. SSRN Electronic Journal pp 1-10

Low A (2016) Brexit is not the will of the British people it never has been. LSE Brexit Blog URL http://blogs.lse.ac.uk/brexit/2016/10/24/ brexit-is-not-the-will-of-the-british-people-it-never-has-been/

Manley D, Jones K, Johnston R (2017) The geography of Brexit What geography? Modelling and predicting the outcome across 380 local authorities. Local Economy 32(3):183-203

Swales K (2016) Understanding the leave vote. NatCen Social Research - The UK in a Changing Europe p 32, URL www . natcen.ac.uk 
Zhang A (2018) New Findings on Key Factors Influencing the UK's Referendum on Leaving the EU. World Development 102:304-314 